Board of Governors of the Federal Reserve System

International Finance Discussion Papers

Number 1028

August 2011

\title{
ABS Inflows to the United States and the Global Financial Crisis
}

\author{
Carol Bertaut \\ Laurie Pounder DeMarco \\ Steve Kamin \\ Ralph Tryon
}

NOTE: International Finance Discussion Papers are preliminary materials circulated to stimulate discussion and critical comment. References to International Finance Discussion Papers (other than an acknowledgment that the writer has had access to unpublished material) should be cleared with the author or authors. Recent IFDPs are available on the Web at www.federalreserve.gov/pubs/ifdp/. This paper can be downloaded without charge from the Social Science Research Network electronic library at www.ssrn.com. 


\title{
ABS Inflows to the United States and the Global Financial Crisis
}

\author{
Carol Bertaut, Laurie Pounder DeMarco, \\ Steve Kamin, and Ralph Tryon
}

This version: August 5, 2011

\begin{abstract}
The "global saving glut" (GSG) hypothesis argues that the surge in capital inflows from emerging market economies to the United States led to significant declines in long-term interest rates in the United States and other industrial economies. In turn, these lower interest rates, when combined with both innovations and deficiencies of the U.S. credit market, are believed to have contributed to the U.S. housing bubble and to the buildup in financial vulnerabilities that led to the financial crisis. Because the GSG countries for the most part restricted their U.S. purchases to Treasuries and Agency debt, their provision of savings to ultimately risky subprime mortgage borrowers was necessarily indirect, pushing down yields on safe assets and increasing the appetite for alternative investments on the part of other investors. We present a more complete picture of how capital flows contributed to the crisis, drawing attention to the sizable inflows from European investors into U.S. private-label asset-backed securities (ABS), including mortgage-backed securities and other structured investment products. By adding to domestic demand for private-label ABS, substantial foreign acquisitions of these securities contributed to the decline in their spreads over Treasury yields. Through a combination of empirical estimation and model simulation, we verify that both GSG inflows into Treasuries and Agencies, as well as European acquisitions of ABS, played a role in contributing to downward pressures on U.S. interest rates.
\end{abstract}

Keywords: Capital Flows; Global Saving Glut; Financial Crisis; Asset-backed Securities; interest rates

JEL Classifications: F3, G1

*This paper was prepared for the NBER-Sloan Project on the Global Financial Crisis. The authors are economists in the International Finance Division of the Federal Reserve Board. The views in this paper are solely the responsibility of the authors and should not be interpreted as reflecting the views of the Board of Governors of the Federal Reserve System or of any other person associated with the Federal Reserve System. We would like to thank Charles Engel, Kristin Forbes, Jeffrey Frankel, Michael Leahy, Andreas Lehnert, Frank Warnock, and conference participants at the Federal Reserve, Bank of Canada, and NBER for helpful comments. James Coonan and Corinne Land provided superb research assistance. 


\section{Introduction}

It is widely accepted that international capital flows played an important role in the emergence of the U.S. housing bubble and the global financial crisis that followed the bursting of that bubble. In this view, an excess of saving over investment in many emerging market economies, popularly referred to as the "global saving glut" (Bernanke, 2005, 2007), led to a surge in capital inflows to the United States that increased available credit and lowered interest rates. In combination with a number of additional factors - the increase in securitization, excessive reliance on credit ratings, increases in leverage, failures to manage liquidity and risk, and inadequacies of supervision and regulation - the expansion of financing associated with the capital inflows contributed to the U.S. housing bubble and to the buildup in financial vulnerabilities more generally that led to the crisis.

However, as noted in a companion paper (Bernanke et al., 2011), the global saving glut (GSG) story is an incomplete description of the developments in international capital markets that contributed to the crisis. The emerging market economies at the center of the global saving glut—China, other Asian developing economies, and the oil exporters—for the most part restricted their U.S. purchases to Treasuries, Agency debt, and other low-risk investments. Their provision of savings to what ultimately proved to be risky borrowers-such as those with subprime mortgages-was indirect, as the massive capital inflows pushed down yields on Treasuries and Agencies, thus increasing the appetite among private investors for alternative assets and lowering yields on them as well. In fact, as we will discuss below, yields on mortgages and mortgage-backed securities fell even more than those on Treasuries.

In considering the factors contributing to the global financial crisis, it is therefore important to address a second feature of international capital flows that has received less 
attention—direct foreign purchases of asset-backed securities (ABS) and other structured products issued in the United States. To establish terminology, throughout this paper, "ABS" refers to mortgage-backed and other asset-backed securities that are "private-label," meaning they are not guaranteed by the GSEs. All securities issued or guaranteed by the GSEs are collectively referred to as Agency securities. By adding to the demand for private-label ABS, foreign acquisitions of these securities - which were especially prominent among European investors - likely contributed to the decline in their spreads over Treasury yields and to the increase in their supply, thus directly increasing the flow of resources to subprime and other risky borrowers. At the same time, foreign purchases of U.S. ABS ensured that when the bubble finally burst, the financial crisis would not be confined to the United States, but would spread throughout the world.

In our paper, we analyze data on international capital flows and portfolio positions in order to describe the evolution, magnitude, and financing of foreign acquisitions of U.S. ABS and structured instruments. We also explore the reasons why foreigners, especially Europeans, purchased so many ABS and similar securities. We compare these acquisitions to those of U.S. Treasuries and Agencies by the "global saving glut" countries in order to examine the relative importance of these flows in creating vulnerabilities leading to the crisis. In particular, we present both regression estimates and simulations of a stylized portfolio balance model to gauge the contribution to the downward pressure on U.S. interest rates from purchases of U.S. Treasuries and Agencies by the global saving glut countries, on the one hand, and from foreign (especially European) acquisitions of U.S. ABS, on the other. However, we note that purchases of Treasuries and Agencies by the global saving glut countries and purchases of ABS by Europeans were hardly independent: By taking U.S. government debt off the market and 
lowering its yields, the acquisitions of the global saving glut countries encouraged European purchases of ABS. This research has ready implications for policy analysis: the better we can identify the underlying roots of the global financial crisis, the better we can identify trends that anticipate future crises and design measures to counteract them.

Our research builds on a number of papers linking the emergence of the global financial crisis to international imbalances. This research has followed two distinct strands. The first of these is the story sketched out above, in which current account surpluses in the emerging market economies increased the global supply of capital, reduced interest rates in the United States and other advanced economies, and thus encouraged the emergence of the bubble in subprime housing mortgages. Caballero, Farhi, and Gourinchas (2009), Jagannathan, Kapoor, and Schaumburg (2009), Obstfeld and Rogoff (2009), and Rajan (2010), among others, all discuss variants of this argument. Members of the official sector, such as Bernanke (2009) and Bini Smaghi (2008) have also highlighted this line of causation.

The second strand of research into international capital flows and the crisis has focused on the extent to which exposure to U.S. dollar assets and dollar liabilities—and particularly to U.S. ABS and other structured instruments—-made foreign economies more vulnerable to financial disruptions once the crisis began. Acharya and Schnabl (2010) assesses whether issuance of asset-banked commercial paper was associated with subsequent financial distress, while Kamin and Pounder (2010) examine whether holdings of U.S. ABS or financing in dollars led to greater declines in bank asset values in different economies during the crisis. Rose and Spiegel (2009) and Ehrman, Fratzscher, and Mehle (2009) examine how exposure to U.S. assets and liabilities may have influenced broader economic developments during the crisis. Baba, 
McCauley, and Ramaswamy (2009) and McGuire and von Peter (2009) both analyze the funding patterns of non-U.S. banks that led to a severe shortage of dollar liquidity once the crisis began.

However, only a few observers have considered whether the substantial acquisitions of U.S. ABS by foreigners, primarily in Europe, might not only have rendered foreigners more vulnerable to a bursting of the subprime housing bubble, but might also have contributed to the emergence of that bubble. Brender and Pisani (2010) describe how European investors complemented the acquisition of safe U.S. assets by emerging market economies through their participation in international "risk-taking chains" which supplied funds for riskier investments in the United States. Caballero (2009) argues that the driving force behind the U.S. housing and financial bubble was not current account imbalances but the rise in global demand for safe assets beyond levels that could be met through creation of genuinely safe securities. Similarly, Johnson (2009) and Borio and Disyatat (2011) argue that gross capital inflows, especially from Europe, may have been more important in explaining U.S. financial developments in the leadup to the crisis than the net inflows from emerging markets associated with current account imbalances.

But this previous research does not provide a thorough-going comparison of the dimensions and effects of the international capital flows associated with the "global saving glut" economies, on the one hand, and those associated with the acquisition of U.S. ABS by the advanced economies, on the other. Our research, together with the related work featured in Bernanke et al. (2011), fills gaps in the evolving literature on the global financial crisis in several respects: by drawing on the full range of available data to build a composite picture of the pattern of global capital flows in the lead-up to the crisis; by explaining why foreigners (especially Europeans) purchased so much ABS and contrasting their motives with those of the global saving glut countries; and by assessing the extent to which foreign acquisitions of U.S. ABS and 
other structured investment products may have added to the factors-specifically, lower interest rates-propelling the emergence of the housing bubble. ${ }^{1}$ However, we do not address the effect of lower interest rates on the U.S. housing market, a critical issue that unfortunately is beyond the scope of this paper.

The first section of the paper establishes that foreign purchases of U.S. ABS were quantitatively important in the financing of U.S. investment, particularly in housing, and compares those purchases with the size of capital inflows from the GSG countries. Section II describes how the different economies used different means to finance their acquisitions of U.S. assets. Section III addresses the different motivations for the acquisition of U.S. assets by the GSG countries and the advanced foreign economies, especially Europe. The fourth section provides some econometric evidence on the impact of foreign demand for U.S. securities on U.S. interest rates, while Section V presents implications from simulations using a stylized portfolio balance model. Section VI concludes.

\section{Quantitative importance of foreign purchases of U.S. ABS}

To analyze the pattern of international capital flows, we combine data from several sources. The Treasury International Capital (TIC) System provides detailed data on the composition of U.S. capital flows and the U.S. external position by country and instrument. To these data we add details from other countries' published external positions, BIS data on international banking positions, and the IMF's Coordinated Portfolio Investment Survey (CPIS), which provides geographic breakdowns of many countries' external securities claims. Finally, the detail available in the TIC data allows us to estimate the composition of other countries'

\footnotetext{
${ }^{1}$ Bernanke et.al. (2011) also compares capital inflows into Treasuries and Agencies from the global saving glut countries with inflows into ABS from other countries, primarily in Europe. Whereas Bernanke et al. (2011) explores the demand for safe assets by the different foreign investors, this paper focuses more on gauging the relative impact on U.S. interest rates of the different types of capital inflows.
} 
claims and liabilities that are not otherwise available. Such estimates help fill out the picture of international capital flows and positions, providing the basis for addressing the role of ABS and other structured products in global imbalances. (See Appendix B for additional details.)

Figure 1 summarizes the evolution of U.S. external liabilities, while Figure 2 compares the flow of foreign capital into U.S. Treasuries and Agencies with that into U.S. corporate bonds. The increase in liabilities that financed the U.S. current account deficit in the years leading up to the crisis was very broad-based (Figure 1). While the stock of U.S. Treasuries and Agencies held by foreigners exceeded foreign holdings of corporate bonds, by 2007 the latter (including ABS) were nearly as large. Moreover, in the years leading up to the crisis, foreign flows into corporate debt were at least as large as those into Treasuries and Agencies (Figure 2). Nearly half of these inflows into corporate bonds involved the purchase of ABS. In addition, much of the non-ABS corporate debt securities purchased by foreigners were in the form of financial debt, floating rate notes, and various structured products, rather than relatively safe conventional nonfinancial corporate bonds. ${ }^{2}$

Another way to gauge the importance of foreign asset holdings is to consider their share of the total outstanding stocks of these assets, shown in Table 1. On the eve of the financial crisis in mid-2007, while foreign holdings of U.S. Treasuries and Agencies were a large share of the amount outstanding — 31 percent_-foreign holdings of ABS were not all that far behind. At 24 percent, they represented a substantial share of the market, certainly enough to have had a material impact on pricing.

However, the geographic distribution of the inflows into these respective securities was quite different. Figure 3 shows the cumulated flows into the same securities as Figure 2, but

\footnotetext{
${ }^{2}$ Albertus, Bertaut, and Curcuru "Has the Crisis Changed Foreign Positions in U.S. Securities?" Federal Reserve staff working paper 2010.
} 
differentiates these inflows by region of origin. Inflows from Emerging Asia and the Middle East were almost entirely in the form of U.S. Treasuries and Agencies, and investors from these countries account for about 60 percent of the inflows into these securities from 2003 up to June 2007. In contrast, inflows from Europe were largely in the form of corporate debt securities; they accounted for about two-thirds of the total foreign purchases of corporate debt and a little over half of the total foreign purchases of ABS. Most of the remaining capital inflows into corporate debt and ABS came from Caribbean financial centers. ${ }^{3}$ The stark differences in the geography of the inflows suggest that ABS played a very different role in the evolution of capital inflows than that described by the global saving glut story.

\section{How did foreign economies finance their acquisitions of U.S. assets?}

One of the most important differences between the foreign (mainly European) acquisitions of U.S. asset-backed securities (ABS) and the purchases of Treasuries and Agencies by the emerging market economies was how these acquisitions were financed. Figure 4 focuses on the three groups of economies most associated with the global saving glut (GSG)—China, other developing Asian economies, and the OPEC countries—and compares their current account surpluses over the period 2003 to 2007 with their acquisition of U.S. securities and their deposits into European banks. ${ }^{4}$ Although the data are incomplete, it is apparent that these economies' acquisitions of foreign assets were financed primarily by their own current account surpluses. It is also apparent that these surpluses financed not only purchases of U.S. assets, but

\footnotetext{
${ }^{3}$ These financial center inflows in turn reflect in large part investments of special purpose vehicles, including those established by European investment banks.

${ }^{4}$ Comprehensive data on overseas asset purchases by these countries not available. Therefore, we have attempted to capture these purchases by combining data on GSG-country acquisitions of U.S. assets, based on U.S. balance-ofpayments, Treasury International Capital (TIC), and Bank for International Settlements (BIS) banking data, with GSG net bank flows to Europe, based on BIS banking data. Unfortunately, data on foreign purchases of non-U.S. securities, which likely represent the largest gap in our coverage, are not available for most GSG countries.
} 
investments in other economies, such as Europe, as well. Data on the allocation of OPEC assets, unfortunately, is especially incomplete, but it is likely that much of their overseas investments went into purchases of European assets and U.S. assets held by third-party custodians and thus not picked up in the TIC data.

By comparison, Europe, which accounted for most of the foreign purchases of U.S. ABS during the period, was running a small current account deficit in aggregate. Accordingly, as shown in Figure 5, the expansion of its claims was financed by a comparable expansion in its liabilities.

The fact that Europe was issuing external liabilities and acquiring external assets in roughly equal quantities does not mean, however, that the net effect of these transactions on U.S. and global financial markets was a "wash." Figure 6 depicts the evolution of Europe's international balance sheet from 2003 to 2007, showing how its acquisition of external claims was financed by issuance of external liabilities. The composition of these flows of claims and liabilities were broadly similar, but the rise in claims included significant amounts of ABS and other complex financial instruments, whereas the rise in liabilities was tilted toward traditional securities and bank deposits.

Specifically, and focusing first on securities, Figure 6 shows that much of Europe's issuance of externally held securities was in the form of equity and sovereign debt, whereas much of its acquisition of external securities was in the form of asset-backed securities and other debt securities issued by foreign financial corporations, most of which ultimately were issued in the United States. ${ }^{5}$ Turning to transactions among banks and other primarily financial

\footnotetext{
${ }^{5}$ Sovereign debt refers to debt issued by governments. While capital inflows to purchase European sovereign debt helped finance the acquisition of external assets by Europe as a whole, there is no presumption that these inflows financed external asset accumulation by European governments themselves. No sovereign debt appears on the asset
} 
institutions, Europe was a net lender abroad to nonbank corporations ("net loans to nonbanks and other"), but was a net recipient of international interbank flows and other deposits from abroad ("net interbank and deposits") during this period. ${ }^{6}$ As became apparent after the financial crisis broke, many European financial institutions were funding their purchases of U.S. assets with short-term dollar-denominated liabilities like commercial paper or bank deposits, much of which attracted U.S. investors (McGuire and von Peter, 2009, Acharya and Schnabl, 2010). ${ }^{7}$

Thus, even though Europe was not running current account surpluses, its financial firms and investors engaged in a process of intermediation which augmented the supply of financing for ABS and related instruments, especially in the United States. As Acharya and Schnabl (2010) note, investment flows from current account deficit countries as well as surplus countries left their imprint on U.S. financial markets.

Of course, some of the investment flows from external deficit countries to the United States were, in essence, recycled flows from external surplus countries to those deficit countries. Figure 7 decomposes Europe's international transactions in debt securities during the 2003-2007 period by the geographical destination of Europe's outward investment (on the claims side) and the source of the inflows (on the liabilities side). Outward investment flowed largely to the

side of the balance sheet shown in Figure 6 because the change in Europe's holdings of foreign sovereign debt over the period was negligible.

${ }^{6}$ Because the gross two-way flows between Europe and the rest of the world are so large for the "Net loans to nonbanks and other" and "Net interbank and deposits" categories, we show only their net flows in Figure 6. "Net loans to nonbanks and other" primarily contains long-term bank loans to nonbank corporations, intercompany loans between nonbank corporations, and certain transactions by brokers. "Net interbank and deposits," in addition to interbank flows and deposits from nonbank residents abroad, also includes estimates of net repurchase agreements transacted by nonbank corporations, such as brokers. These two categories are derived from and completely cover the "Other Investment" category of the Financial Accounts of the balance of payments of the euro area and the United Kingdom. But in order to present these categories on the basis shown in Figure 6, we also used data from the BIS, individual European countries' Financial Accounts, and the U.S. Financial Account.

${ }^{7}$ It should be noted that not all of the dollar funding of U.S. ABS by Europeans is captured by these data. In many cases, U.S. subsidiaries of European institutions, including their off-balance-sheet vehicles, both received dollarfunding and purchased ABS in the United States or the Caribbean; accordingly, these transactions did not give rise to the cross-border financial flows with Europe shown in Figure 6. This is particularly true of dollar funding through commercial paper vehicles. 
United States and offshore centers, whereas most of the expansion in Europe's liabilities is accounted for by increased holdings of its bonds in the international reserves of other countries as well as a large residual category, comprising mainly EMEs and offshore centers. Most likely, both the international reserves and the EME residual category are largely accounted for by liabilities to the global saving glut economies.

Hence, the global saving glut countries not only provided financing to the United States directly through purchases of U.S. assets, but also indirectly through purchases of European assets that in turn financed purchases of U.S. assets. Moreover, European liabilities to the saving glut countries were primarily in the form of safe assets such as government bonds and bank deposits, whereas many European claims on the United States were in the form of ABS and other structured credit instruments that later proved Stylized flows
by ex post riskiness of asset quite risky. Accordingly, Europeans had considerable exposure to the subsequent crisis (as illustrated by the diagram of the "triangular trade" in financial assets). Ironically, in this regard Europe was acting as an international hedge fund, a role that previously had been attributed to the United States.

To be sure, most U.S. ABS was rated

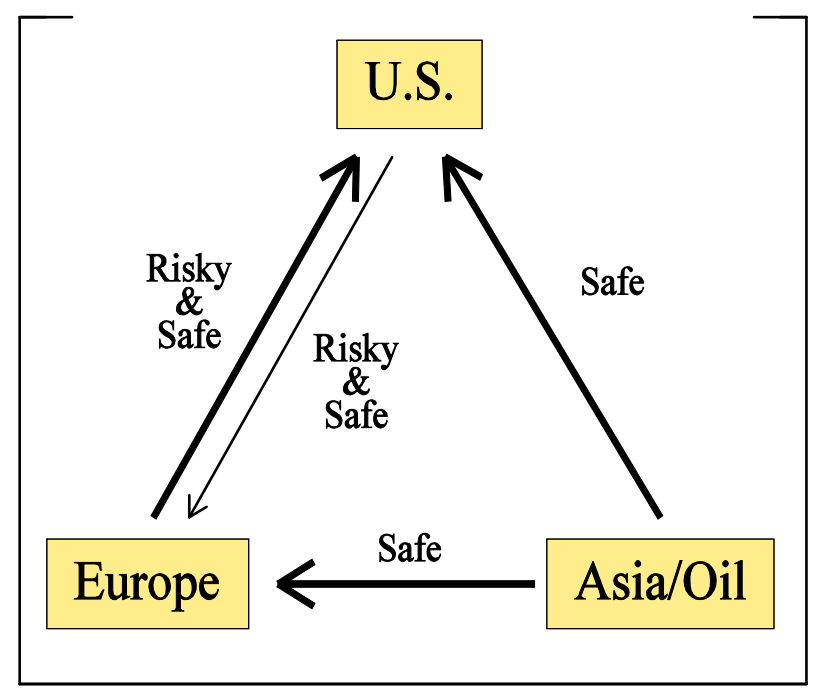
AAA, and investors both in the United States and abroad believed they were acquiring very safe assets (Bernanke et al., 2011). But even so, these investors were happy to accept some additional yield in exchange for investments that were not as gold-plated as U.S. Treasuries, and they 
intended to exploit the difference between the cost of short-term deposits and commercial paper, on the one hand, and the return on U.S. ABS and other corporate debt, on the other.

\section{Motivations for investment flows into the United States}

What motivated the different types of investors we have discussed above to purchase U.S. assets? This question is interesting in its own right, and also has a bearing on whether capital inflows contributed to the U.S. housing boom and subsequent bust. To the extent that these capital inflows were largely exogenous to financial developments within the United States - that is, the capital was pushed into the country - this strengthens the case that such flows lowered U.S. interest rates and contributed to the boom and bust cycle. Conversely, if capital flows were an endogenous reaction to U.S. developments- that is, they were pulled into the United States by the prospect of high returns - this weakens the case for an independent effect of foreign inflows.

Certainly, most observers would characterize the capital inflows from the GSG countries as being relatively predetermined with respect to U.S. financial market developments in general and the sub-prime bubble in particular. There is no consensus regarding the causes of the current account surpluses generated by these countries; candidate explanations include high saving rates, intentional currency undervaluation, precautionary reserve accumulation, rising commodity prices, and the desire to acquire the high-quality financial assets created in advanced economies. ${ }^{8}$ But there is general agreement that, whatever the sources of these surpluses, the GSG countries have been investing them in assets regarded as very safe and liquid, with little regard to their rate of return. Because U.S. Treasuries and Agencies represent the global benchmark for safe, liquid, assets, acquisitions of these instruments have comprised a large share of the GSG countries'

\footnotetext{
${ }^{8}$ See, among others, Dooley, Folkerts-Landau and Garber (2003), Gruber and Kamin (2007, 2009), Ju and Wei (2006), Mendoza, Quadrini, and Rios-Rull (2007), and Caballero, Farhi, and Gourinchas (2008).
} 
asset purchases (Blanchard, Giavazzi, and Sa, 2005; Clarida, 2005; Cooper, 2005; Hubbard, 2005). Thus, taking the current account surpluses run by the GSG countries as given, the capital generated by those surpluses appears to have been pushed toward the United States rather than pulled by it.

The factors underlying the sizeable inflows of capital from Europe and other industrial economies are more varied and complex. Some of the most prominent of these are the following:

Rising wealth Figure 8 shows that the dollar value of gross European financial wealth (excluding the volatile equity component) rose sharply during the years prior to the financial crisis, and more rapidly than that of the United States. The \$13.6 trillion rise in European holdings of debt securities from the end of 2002 to the middle of 2007 meant that, even if the share of U.S. assets in those assets had remained constant at its end-2002 level of 6 percent, Europe would have had to acquire an additional $\$ 800$ billion in U.S. assets.

To be sure, some of the rise in the dollar value of European wealth reflected valuation effects from the fall in the dollar rather than accumulation of additional wealth per se; as shown in Figure 9, when measured as a ratio of GDP, European wealth grew more slowly than it did in absolute dollar terms. But valuation changes can affect portfolio decisions just as readily as asset accumulation. Put another way, the fall in the dollar reduced the share of U.S. assets in European portfolios, so it was natural for them to purchase more of these assets to restore balance to their portfolios. 
Falling home bias $^{9}$ Europeans were not acquiring U.S. assets solely to maintain the shares of these assets in their portfolios, however. They were also boosting the shares in their portfolio of external assets in general, and U.S. assets in particular, thereby bringing these shares closer to the levels consistent with global market capitalizations. The $\mathrm{X}$-axis of Figure 10 plots the evolution of Europeans' relative portfolio weight in all externally-issued bonds: A value of 1 indicates that the share of the external bonds in Europe's portfolio was equal to the share of the external bonds' value in the total global value of bonds outstanding (i.e., no home bias); a value of zero indicates that none of the foreign bonds were being held (complete home bias). ${ }^{10}$ The $y$ axis computes Europeans' relative portfolio weight in U.S.-issued bonds: Again, a value of 1 indicates that the share of U.S. bonds in European portfolios was equal to their share in global market capitalization, while a value of zero indicated no U.S. bonds were being held. The figure indicates that in 2002, Europe started with considerable home bias in its holdings of all external bonds (a portolio weight of only about .19), and even more home bias against holdings of U.S. bonds (a portfolio weight of .14). However, by 2007, Europe had reduced its home bias against both externally-issued bonds in general and U.S. bonds in particular, boosting the shares of both in its portfolio. Thus, even if the dollar value of Europe's total securities holdings (both domestic- and externally- issued) had remained constant between 2002 and 2007, the reduction in bias against U.S. holdings would have, by itself, accounted for $\$ 150$ billion in acquisitions of U.S. debt securities.

Role of $A B S$ It is difficult to determine how much of Europe's overseas acquisitions during the 2003-2007 period were motivated by the desire to reduce home bias (i.e., internationally

\footnotetext{
${ }^{9}$ Home bias refers to the extent to which a country's holdings of external assets as a share of its total portfolio fall short of the standard CAPM benchmark: the share of total external market capitalization in global market capitalization.

${ }^{10}$ For a more detailed description of this measure, see Bertaut and Kole (2004).
} 
diversify) in general and how much they were motivated by the demand for specific types of instruments, such as ABS. Purchases of ABS and other structured products stand out as a significant component of the buildup in Europe's cross-border positions, not only vis-à-vis the United States, as noted earlier, but against all foreign (to Europe) counterparties. Figure 11 shows Europe's holdings of long-term debt securities. Using TIC data, we can identify European-held U.S. ABS and additionally estimate ABS issued in other countries, especially offshore centers. Moreover, the bar segments labeled "U.S. corporate bonds other than ABS" and "offshore bonds, other than ABS" may in fact contain some ABS, as well as other structured products and financial-sector debt. All told, though it is difficult to distinguish with certainty among the different types of instruments held, it is evident that ABS and other structured debt instruments played an important role in the expansion of external assets in the United Kingdom and the euro area.

The role of ABS and other structured debt in financial globalization is illustrated more starkly in Figure 12. This figure identifies the part of the reduction in "home bias" for a number of advanced economies between 2003 and 2007 that is attributable to increased acquisitions of ABS and other structured products. In the figure, reductions in home bias are expressed as positive values - the red portions of the bars represent the reduction in home bias associated with expanded holdings of ABS, while the blue portions represent reductions in home bias associated with acquisitions of other debt securities. For most of the economies examined, ABS accounted for a substantial part of the change in portfolios associated with a reduction in home bias during the period.

One of the reasons why ABS accounted for so much of the expansion of Europe's crossborder assets, of course, is that most of the ABS was being issued outside of Europe, so 
European investors had perforce to engage in cross-border transactions to acquire it. Figure 13 shows that from 2002 to 2007, the United States accounted for nearly 80 percent of the global issuance of ABS, whereas Europe accounted for only 15 percent.

But what accounts for the Europeans' interest in U.S. ABS? To begin with, the investment strategies of European financial institutions were not all that different than those of similar institutions in the United States and other parts of the world. Figure 14 describes the evolution of the composition of U.S. holdings by U.S. and foreign residents. Between 2003 and 2007, the share of ABS in the portfolios of both European residents (the third set of panels) and U.S. residents (the fourth set) expanded significantly as the shares allocated to Treasuries and agencies declined. ${ }^{11}$ Although the share of European holdings allocated to ABS grew by more than did the ABS share of U.S. residents' holdings, this in large part appears to reflect the Europeans' greater taste for fixed income securities than for equities; focusing on their fixedincome portfolios alone, the share of ABS rose by broadly similar margins for Europeans and U.S. residents. Research by Arteta et al. (2010) also suggests that Europeans did not have a higher intrinsic demand for ABS. Arteta et al. show that large, global banks were especially likely to sponsor the vehicles that purchased ABS financed with commercial paper, and most of those banks were headquartered in Europe; in a regression explaining bank sponsorship of ABS vehicles, a dummy variable for U.S. banks is not statistically significant.

Therefore, the factors that explain European interest in ABS were likely similar to those motivating investors in the United States and elsewhere. Most obviously, ABS was overwhelmingly rated AAA, and so appeared very safe while offering slightly higher returns than Treasuries and Agencies (Bernanke et al., 2011). But some observers argue that the demand

\footnotetext{
${ }^{11}$ Clearly, the global saving glut countries had little interest in these instruments: The share of ABS in their holdings of U.S. assets remained below 2.5 percent by the end of the period.
} 
for $\mathrm{ABS}$ reflected not just a failure to understand the risks, as manifested in misleadingly high ratings, but also agency problems and flawed risk-management systems within the intermediation system (Kashap, Rajan, and Stein, 2008; Arteta et al., 2010): Financial industry participants were well-compensated for acquiring assets earning high returns during good times, but were not penalized for creating exposure to adverse tail risks during bad times. By the same token, industry participants faced few disincentives to acquiring substantial short-term liabilities during periods of high liquidity, even though this made them vulnerable to runs during periods of market stress. And perhaps banks' risk-return tradeoff was distorted by implicit or explicit government guarantees. For example, debt issued by the German Landesbanks prior to 2005 carried explicit state guarantees through 2015 and Arteta et al. (2010) find that Landesbanks were more likely than other banks to sponsor credit arbitrage vehicles, all else equal.

Finally, some observers have argued that the regulatory capital charges levied on banks that set up off-balance-sheet conduits to invest in U.S. ABS were inadequate, which also served to encourage investments in these assets (Acharya and Schnabl, 2010). Banks incurred little or no capital charges for the liquidity guarantees provided to conduits. These guarantees backstopped a highly profitable scheme, ensuring high ratings on the conduits' $\mathrm{ABCP}$ issuance, and allowing the sponsoring bank to pocket the difference in yields between these short-term ABCP liabilities and the conduits' long-term ABS assets. Acharya and Schnabl (2010) argue that these regulatory incentives applied to banks in both the United States and Europe. Role of Interest Rates A recurrent issue in discussions of the U.S. subprime housing boom is the role played by U.S. monetary policy. It is beyond the scope of this paper to address the contribution of the very low federal funds rate in the 2002-2004 period to the U.S. housing 
boom, sub-prime lending, or the securitization process in general. ${ }^{12}$ However, it bears asking whether the evolution of U.S. policy rates influenced the large European acquisitions of U.S. assets, especially ABS. As shown in the top panel of Figure 15, policy interest rates in the United States, the United Kingdom, and the euro area all dipped in response to the mild economic recession early in the decade, but U.S. rates clearly fell the most. According to standard international economic theory, this differential should have triggered capital flows from the United States toward Europe. But this theory ignores the fact that most banking activity avoids exchange rate exposure and seeks to maintain a "matched book" between the currency denomination of assets and liabilities. The remaining panels of Figure 15 present data on what may have been a more relevant consideration, the differential between the yield on highly rated corporate bonds and short-term funding costs, as proxied by the countries' respective policy interest rates. By this measure, the profitability of corporate bonds funded by short-term debt was highest in the United States during the 2002-2004 period, and along with other factors described above likely played a role—just how large is difficult to say—in encouraging European financial institutions to simultaneously take on long-term U.S. corporate assets (including ABS) financed by short-term dollar liabilities.

By the 2005-2006 period, however, increases in the federal funds rate had sharply depressed the profitability of U.S. ABS, both in absolute terms and relative to similar measures for the United Kingdom and the euro area. Even so, creation of subprime loans peaked during this period (Figure 17), as did European purchases of corporate bonds, including ABS (Figure 2).

\footnotetext{
${ }^{12}$ For discussions of the role of U.S. interest rates in the runup to the crisis, see, among others, Taylor (2008), Dokko et.al. (2009), Glaeser, Gottlieb, and Gyourko (2010), and Sa, Towbin, and Wieladek (2011). For analysis of subprime lending and securitization, see, among others, Coval, Jurek, and Stafford (2008), Gerardi, Lehnert, Sherlund, and Willen (2008), Mayer, Pence, and Sherlund (2009), Acharya and Schnabl (2010), Demyanyk and Van Hemert (2009), Kashyap, Rajan, and Stein (2008), and Ashcraft, Goldsmith-Pinkham, and Vickery (2010).
} 
Why did Europeans continue to acquire these assets, even after their ex ante return, net of carrying costs, had diminished so greatly? ${ }^{13}$ The answers are probably the same as those explaining why U.S. and other investors more generally continued to buy ABS: Strong housing price appreciation had substantially held down delinquencies on subprime mortgages, allowing ABS to develop a track record of dependability and an illusion of safety (Gerardi, Lehnert, Sherlund, and Willen, 2008; Demyanyk and van Hemert, 2009). Analysts deeply discounted the possibility of a decline in housing prices, and thus assumed subprime mortgages would continue to be serviced (Gerardi, Lehnert, Sherlund, and Willen, 2008). Low yields and low spreads on other assets reduced the incentives for investors to shift their portfolios toward other investments. And, more generally, a culture of risk-taking had evolved among banks that centered importantly around securitization, and the credit boom developed a momentum of its own in this context (Diamond and Rajan, 2008; Demanyanyk and van Hemert, 2009).

\section{Summing up}

Putting the pieces together, growing European demand for U.S. assets (fed by rising wealth, increasing international diversification, a new global bank business model, and regulatory incentives) combined with rising supply of U.S. ABS (fed in part by the sub-prime housing boom and financial industry incentives) to produce sizeable European acquisitions of these instruments. To return to the question posed at the beginning of the section, in explaining the European capital flows into the United States, both push and pull factors appear to have been at work.

\section{Impact of capital inflows on U.S. interest rates-data and reduced-form estimates}

\footnotetext{
${ }^{13}$ Not only did the differential between promised returns and funding costs narrow, but evidence suggests that mortgage underwriting standards slipped and assets with the same credit rating became riskier during this period (Demyanyk and van Hemert, 2009; Ashcraft, Goldsmith-Pinkham, and Vickery, 2010; Mayer, Pence, and Sherlund, 2009).
} 
How might purchases of Treasuries and Agencies by the global saving glut (GSG) countries and purchases of asset-backed securities (ABS) by Europeans and others have affected financial conditions in the United States? In particular, how might they have affected yields on asset-backed securities which, in turn, would have affected the costs of mortgage borrowing by households and thus influenced the evolution of the housing bubble? To address this question, we adopt two distinct but related strategies: First, in this section, following on Warnock and Warnock (2009), we estimate reduced-form models that link U.S. interest rates to, among other factors, foreign capital inflows. Second, in Section V below, we develop and simulate a highly stylized portfolio balance model in order to illustrate how different types of capital inflows might have affected yields on different types of U.S. assets. Before describing this work, however, we first review the salient trends in U.S. interest rates in the years before the financial crisis.

\section{IV.1 Trends in U.S. interest rates}

The top left panel of Figure 16 illustrates the signal development of this period, the low level of long-term Treasury security yields, which remained relatively contained even as the federal funds rate was raised from 1 percent to an eventual level of 51/4 percent. Greenspan (2005) famously referred to this development as a "conundrum," and various studies showed that bond yields, both in the United States and abroad, fell below levels that were consistent with standard macro fundamentals such as inflation, growth in gross domestic product, and fiscal balances (Rudebusch, Swanson, and Wu, 2006; Gruber and Kamin, 2009). Explanations for the weakness in Treasury yields during this period include declines in risk premiums (perhaps, at least initially, associated with the "great moderation") and enhanced demands for long-term assets by pension funds and other institutional investors. In addition, observers have come to attribute at least part 
of the weakness of Treasury yields to the subject of this paper, the heavy purchases of securities by foreigners.

As is evident in the remaining panels of Figure 16, during this period interest rates on Agency (Fannie Mae) MBS, AAA corporate bonds, and conforming (Agency-guaranteed) 30year fixed mortgages also fell significantly. While part of the weakness in these rates obviously was due to the low Treasury yields, these rates declined even more than Treasury yields, so that the spread of these different yields over Treasuries also edged down over the period, notwithstanding a sharp step-up in the pace of issuance of these assts. ${ }^{14}$ Accordingly, these declines in yields may have reflected more than just spillovers from falling Treasury yieldsthey may also have reflected increases in demand for the non-Treasury securities themselves.

These developments were also evident in the markets most relevant to the U.S. subprime housing boom. The top left panel of Figure 17 displays rates on subprime mortgages (shown here as the origination rates on subprime ARMs), which declined roughly 250 basis points from 2000 through 2006; the spread between subprime ARMs and conforming (Agency-guaranteed) ARMs moved down as well. This decline in subprime spreads is quite remarkable, given the explosion in the number of subprime loans issued over this period: subprime originations grew nearly 20 -fold, far faster than issuance of Treasuries. The bottom panels show similar developments for Alt-A ARMs; here, there is a more pronounced decline in the spread over conforming ARMs, even in the face of a substantial increase in Alt-A issuance.

\section{IV.2 Reduced-form estimates of the effect of capital inflows on U.S. interest rates}

To gauge the impact of capital inflows on U.S. interest rates, we start by building on the work of Warnock and Warnock (2009) and examining the effect of foreign official purchases of

\footnotetext{
${ }^{14}$ For example, the outstanding stock of MBS and unsecuritized mortgages rose from $\$ 6.4$ trillion at the end of 2002 to $\$ 11.1$ trillion in 2007 .
} 
U.S. Treasuries on Treasury yields. Most of these purchases came from countries associated with the global saving glut, so they could reasonably be described as exogenous to the Treasury yields themselves - China and other Asian countries were intervening to buy dollars in foreign exchange markets and channeling the proceeds into U.S. Treasuries and Agencies in a fairly stable allocation. To estimate the effect of these purchases, we use a variant of the single equation OLS specification in Beltran, Kretchmer, Marquez, Thomas (2011), which reformulates the Warnock and Warnock model as an $\mathrm{AR}(1)$ after extensive testing of alternative specifications: ${ }^{15}$

$$
R_{10, t}=f\left(R_{10, t-1}, \widehat{Y_{t}^{e}}, \pi_{t+10}^{e}, r p_{t}, R_{f f, t}, \frac{F_{t}}{D_{t}}\right)
$$

$R_{10, t}: 10$-year U.S. Treasury yield, nominal

$\widehat{Y_{t}^{e}}:$ expected GDP growth (blue chip)

$\pi_{t+10}^{e}$ : expected inflation rate (10-year ahead Michigan survey)

$r p_{t}$ : risk premium (36-month standard deviation of changes in Treasury yields)

$R_{f f, t}:$ federal funds rate

$F_{t}$ : foreign official holdings of U.S. Treasuries and Agencies

$D_{t}$ : total outstanding marketable U.S. Treasuries and Agencies

\footnotetext{
${ }^{15}$ Our specification differs from that employed by Warnock and Warnock (2009) in a number of ways. First, it introduces a lagged dependent variable, which is highly significant and required to help control serial correlation of the error term. Second, it uses the stock of foreign official holdings as the dependent variable rather than the flow of purchases employed by Warnock and Warnock (2009); this conforms more closely with the view embodied in portfolio balance models that it is the stock rather than the flow of asset supplies and demands that best explains asset prices. One concern with using a stock formulation of foreign holdings is that they trend upward over time and their estimated negative impact on interest rates is spuriously reflecting a downward trend in interest rates for other reasons. However, inclusion of a time trend in the regressions shown in Table 2 (not shown) does not reduce the estimated effect of the foreign holdings variable.
} 
The equation is estimated using quarterly data for the period 1990 through the first half of 2007. The first column of Table 2 presents the estimation results. The foreign official share of Treasuries and Agencies significantly decreases Treasury yields, just as in Warnock and Warnock (2009). The long-run effect of a one percentage point rise in this share is to depress Treasury yields by 7 basis points. Evaluated using the level of outstanding Treasuries and agencies in June 2007, this implies that $\$ 100$ billion in foreign official inflows depresses Treasury yields by 11 basis points. The table below compares this estimated effect of Treasury purchases with that derived from other studies, including some also focusing on the effect of foreign capital inflows on yields (Warnock and Warnock, 2009, Beltran et al., 2011, and Rudebusch, Swanson, and Wu, 2006) and others focusing on the effects of the Federal Reserve's recent asset purchase programs (Gagnon et al., 2010, D’Amico and King, 2010, and Hamilton and $\mathrm{Wu}, 2010)$. The estimated effects in these studies are quite dispersed, and our own estimates seem to fall squarely within their range.

\begin{tabular}{|l|c|}
\hline \multicolumn{1}{|c|}{ Study } & $\begin{array}{c}\text { Impact of \$100 billion in U.S. } \\
\text { Treasury/Agency purchases on } \\
\text { Treasury yields (basis points) }\end{array}$ \\
\hline Bertaut et al. (2011): Reduced form regression & -11 \\
\hline $\begin{array}{l}\text { Bertaut et al. (2011): Portfolio balance model } \\
\text { (section V, below) }\end{array}$ & -15 \\
\hline Warnock and Warnock (2009) & -15 to -32 \\
\hline Beltran et al. (2011) & -49 \\
\hline Rudebusch, Swanson and Wu (2006) & no significant effect \\
\hline Gagnon et al.(2010) & -6 \\
\hline D'Amico and King (2011) & -10 \\
\hline Hamilton and Wu (2010) & -4 \\
\hline
\end{tabular}

Taking our own estimates and applying them to the roughly $\$ 1$ trillion in Treasury and Agency acquisitions by the GSG countries during the 2003-2007 period, this suggests that those inflows lowered U.S. Treasury yields by 110 basis points. But to what extent did these declines 
spill over into other interest rates such as those on housing mortgages? Unfortunately, foreign holdings of ABS are only available beginning in 2002; this implies only 20 quarterly observations of our key independent variable, too few to generate reliable estimation results. Moreover, the markets for subprime loans and for private label MBS did not achieve substantial depth and liquidity until the 2000s.

However, we can gain some sense of the likely spillovers of foreign purchases of U.S. Treasuries and Agencies into other markets by estimating the effect of these purchases on the yields shown in Figure 16: corporate AAA, Fannie Mae guaranteed MBS, and 30-year fixed-rate conforming mortgages. The results of these estimations are also shown in Table 2. They confirm that foreign official purchases of Treasuries and Agencies had significant spillovers to other markets, significantly depressing yields on Fannie Mae MBS, AAA corporate bonds, and fixed-rate mortgages. Moreover, the size of these effects appears similar to, and usually larger than, the effects on U.S. Treasury yields themselves, suggesting a great deal of substitutability between Treasuries and other bonds. ${ }^{16}$

All told, these results suggest that inflows from the GSG countries depressed other private yields by well upwards of 100 basis points by 2007 . However, they do not shed light on the size of the additional impact on yields of direct purchases of ABS and other corporate debt securities by Europe and other non-GSG countries. This impact is more difficult to estimate, as, unlike foreign official inflows, European purchases of U.S. corporate securities are likely to be endogenous with respect to the yields on those assets. For this reason, we instead examine illustrative simulations of a stylized portfolio balance model in Section V below.

\footnotetext{
${ }^{16}$ Warnock and Warnock (2009) look at the effect of all foreign purchases (both private and official) of Treasuries and Agencies on the yields on corporate bonds and mortgage interest rates, and get similar results.
} 
However, to shed at least some light on this issue before describing those simulations, the last column of Table 2 presents a regression of AAA corporate yields on foreign acquisitions of corporate bonds. The coefficient on this variable is significant, and implies that the 7.5 percentage point rise in the foreign share of U.S. corporate bonds outstanding between 2002 and June 2007 depressed AAA corporate yields by 95 basis points. Moreover, the coefficient is likely biased upwards (less negative) by the endogeneity problem, as feedback from shocks to corporate bond yields should lead to increases in the same direction of foreign purchases of these bonds.

\section{A calibrated portfolio balance model of asset demands and supplies}

To complement the econometric results discussed above and to develop more intuition into the ways in which foreign capital flows may have affected U.S. interest rates, this section considers a stylized portfolio balance framework with three assets: (1) bank deposits; (2) U.S. Treasuries and Agencies (which, for convenience, we will refer to as "Treasuries"); and (3) U.S. corporate debt, including the focus of our interest, asset-backed securities (ABS). ${ }^{17}$ These assets are demanded by residents of three different economies: the United States, Europe, and the global saving glut countries (referred to, again for convenience, as "China”). All assets are freely exchanged between investor countries at fixed exchange rates (admittedly a more plausible assumption for China than for the United States and Europe).

We assume asset supplies are exogenous, so that reductions in interest rates caused by capital inflows do not elicit additional issuance of securities. This assumption is unavoidable,

\footnotetext{
${ }^{17}$ We model the broader category of corporate debt rather than its narrower ABS sub-component for a number of reasons. First, most ABS received AAA credit ratings and, before the crisis, were perceived to be comparable in quality to other highly-rated corporate securities. Second, as noted earlier, much of the non-ABS corporate debt held by European investors was in the form of financial debt, floating rate notes, and structured products that were similar in many respects to ABS. Finally, as noted in section IV, we do not have sufficiently long time series on either holdings of $\mathrm{ABS}$ or their yields to permit reliable estimation of a demand equation for ABS, whereas we do have such data for corporate debt more generally.
} 
because tenuous as are our estimates of the parameters of asset demands (see below), even less information is available on the parameters of asset supply. As a consequence, our analysis focuses on comparing the notional downward pressures on U.S. interest rates posed by different types of capital inflows; the actual downward pressures may have been somewhat less, as they would have been moderated by increased securities issuance in response to the lower interest rates.

\section{V.1 Basic Framework}

Let, $b$ stand for bank deposits, $t$ for Treasury securities, and $c$ for U.S. corporate debt, including ABS. In this framework, demand for each asset A in each country as a share of wealth $\mathrm{W}$ takes the form:

$$
\begin{aligned}
& \frac{A_{b}}{W}=b_{0 b}+\beta_{b b} r_{b}-\beta_{b t} r_{t}-\beta_{b c} r_{c} \\
& \frac{A_{t}}{W}=b_{0 t}-\beta_{t b} r_{b}+\beta_{t t} r_{t}-\beta_{t c} r_{c} \\
& \frac{A_{c}}{W}=b_{0 c}-\beta_{c b} r_{b}-\beta_{c t} r_{t}+\beta_{c c} r_{c}
\end{aligned}
$$

Demand for each asset thus consists of an intercept term, and then is positively related to its own interest rate and negatively to the interest rates on other assets. Our model will solve for the various changes in interest rates that result from different configurations of investor preferences.

The assumptions regarding the demand curve parameters used in our analysis are listed in the table below. Details of their derivation are described in Appendix A. In short, these parameters were derived from IV estimations of the demand system described in equation (2) above, applied to U.S. and European financial data over the period 1980 to 2007. However, for a number of reasons, these parameters (and the model incorporating them) should be regarded as illustrative rather than a precise representation of actual asset demands. First, asset demand 
systems are notoriously difficult to estimate, and we had few previous results to draw upon.

Second, one of the reasons for the sparseness of previous results is the lack of suitable instruments to distinguish shocks to asset demands from those to asset supplies; we used lagged values of the variables in the model as instruments, but it is unclear how effective this approach really is. Third, in reality investor portfolios are comprised of other assets besides deposits, Treasuries, and U.S. corporate debt, and this also compromises the accuracy of the parameters of interest. The results discussed in this section use our "baseline" simulation coefficients; in Table 3 , we also show the sensitivity of the results to somewhat higher and lower elasticities calibrated from the estimated standard errors of the portfolio balance model.

With these caveats in mind, a number of features of the parameters we use are worth highlighting. First, for China, we assume, consistent with much anecdotal evidence and observed behavior, that their asset demands are invariant with respect to interest rates, so their parameters are all set equal to zero. Second, we assume identical demand sensitivities for the United States and Europe, both for convenience and because the composition of their U.S. asset holdings, shown in Figure 14, is indeed fairly similar.

The parameters shown below represent the change in the share of a given asset in investors' wealth, expressed in decimal form, resulting from a 1 percentage point rise in a given interest rate, all else equal. For example, a 1 percentage point rise in Treasury yields (say, from 4 percent to 5 percent), all else equal, would induce a rise in the ratio of Treasuries holdings to total wealth of .36 (say, from .30 to .66) and a corresponding fall in the ratio of corporate debt to wealth of .54 (say, from .64 to .10). These appear to be huge swings in asset shares for comparatively modest changes in interest rates. However, as indicated in Figure 16, interest rates on Treasuries and corporate debt tend to move up and down together. Therefore, it would 
be unusual for Treasury yields to move 1 percentage point without some accompanying movement in corporate yields, which would moderate the response of portfolio shares.

Finally, the parameters suggest very little substitutability between either Treasuries or corporate debt, on the one hand, and deposits, on the other. By implication, the parameters suggest more substitutability between Treasuries and corporate debt, consistent with the results of the reduced-form equations described in Section IV.2

\begin{tabular}{|c|c|c|c|}
\hline \multicolumn{4}{|c|}{$\begin{array}{l}\text { Portfolio Balance Model Coefficient Settings: Sensitivity of Asset } \\
\text { Demands to Interest Rates on Different Assets }\end{array}$} \\
\hline & $\begin{array}{l}\text { Treasuries \& } \\
\text { Agencies }\end{array}$ & \begin{tabular}{|c|} 
Corporate \\
Bonds (including \\
ABS) \\
\end{tabular} & Deposits \\
\hline & \multicolumn{3}{|c|}{ Baseline Sensitivities } \\
\hline & \multicolumn{3}{|c|}{ US } \\
\hline Treasury \& Agency demand & 0.37 & -0.28 & -0.09 \\
\hline \multirow[t]{2}{*}{ Corporate Demand } & -0.55 & 0.46 & 0.10 \\
\hline & \multicolumn{3}{|c|}{ Europe } \\
\hline Treasury \& Agency demand & 0.37 & -0.28 & -0.09 \\
\hline \multirow{2}{*}{ Corporate Demand } & -0.55 & 0.46 & 0.10 \\
\hline & \multicolumn{3}{|c|}{ China } \\
\hline Treasury \& Agency demand & 0 & 0 & 0 \\
\hline \multirow[t]{2}{*}{ Corporate Demand } & 0 & 0 & 0 \\
\hline & \multicolumn{3}{|c|}{ Global } \\
\hline Treasury \& Agency demand & 0.35 & -0.27 & -0.08 \\
\hline Corporate Demand & -0.53 & 0.44 & 0.09 \\
\hline
\end{tabular}

Once the parameters of the model are set, global demand can then be expressed as the averages of demands for the individual assets in each country, weighted by the shares of each country's wealth in global wealth. In equilibrium, the global demand for each asset must equal the fixed asset supply. We set initial stocks of assets and levels of country wealth to be roughly comparable to levels of bank deposits held in Europe and the United States, Treasury (and Agency) securities held by the public, and U.S. corporate debt outstanding in 2003. In our 
simplified version, corporate debt, including ABS, is held exclusively by the United States and Europe.

Because the securities in our model include only those issued by the United States (and given the home bias in portfolios), the United States has roughly twice the financial wealth of Europe. Europe holds most of its wealth in deposits; its holdings of $\$ 400$ billion in corporate debt and \$1 trillion in Treasuries are roughly comparable to the stocks of U.S. corporate debt and Treasuries and Agencies actually held by Europe in 2003. "China" has wealth of $\$ 1,000$ billion, which is roughly the size of the combined foreign exchange reserves of Asian and OPEC countries in 2003. "China's" wealth is held in equal amounts of deposits and Treasuries (and Agencies); the $\$ 500$ billion assumption for Treasuries is roughly the stock of U.S. Treasuries and Agencies held collectively by emerging Asia/OPEC in 2003.

\begin{tabular}{|l|r|r|r|r|}
\hline \multicolumn{5}{|c|}{ Initial Asset Stocks and Country Wealth Allocations } \\
\hline & Total (bill \$) & United States & Europe & China \\
\hline Deposits & 11750 & 5425 & 5825 & 500 \\
\hline Corporate debt & 5400 & 5000 & 400 & 0 \\
\hline Treasuries & 8000 & 6500 & 1000 & 500 \\
\hline Total Wealth & 25150 & 16925 & 7225 & 1000 \\
\hline
\end{tabular}

Expressed in portfolio share terms, asset holdings in each country are depicted in the table below. The b0 coefficients in the asset demand equations depicted in equation (2) are calculated residually, as the value that sets the $\frac{A_{b}}{W}$ term, for example, equal to $\beta_{b b} r_{b}-\beta_{b t} r_{t}-$ $\beta_{b c} r_{c t}$ 


\begin{tabular}{|l|r|l|r|}
\hline \multicolumn{5}{|c|}{ Initial Portfolio Shares } \\
\hline & United States & Europe & China \\
\hline Deposits & .32 & .81 & .5 \\
\hline Corporate debt & .30 & .06 & 0 \\
\hline Treasuries & .38 & .14 & .5 \\
\hline
\end{tabular}

Finally, because the three demand equations are not independent of each other-the asset demands for each country must sum to its total wealth—-the system as specified is underdetermined: there are not enough independent equations to determine all three interest rates. Accordingly, we assume the interest rate on bank deposits is fixed. This is not implausible, as this rate likely closely follows the short-term policy rate set by the monetary authority, and does not vary greatly with movements in longer term rates. Conversely, the interest rates on Treasuries and ABS are more volatile and less anchored by the policy rate.

\section{V.2 Simulation exercises}

With this framework, we consider the following comparative static exercises. First, to evaluate the impact of the global saving glut, we analyze the impact on yields of a step-up in Chinese purchases of Treasuries. Second, as one measure of the effect of capital inflows from the advanced economies, we perform a simulation in which European investors boost the desired share of U.S. ABS in their portfolios; this corresponds to the case, described in Section III above, in which capital flows were pushed into the U.S. financial system. Third, as an alternative measure of the role of foreign advanced-economy investors in the evolution of U.S. interest rates, we consider a scenario in which foreign investors' demand curve for U.S. ABS and other corporate debt is unchanged, but they purchase more of it as the supply of ABS by U.S. residents 
increases; this corresponds to the possibility discussed in Section III that capital inflows from Europe and elsewhere were pulled into the country by the housing boom.

The implications of these simulations for Treasury and ABS yields are shown in Table 3. The first set of columns is based on the baseline sensitivities shown above. The remaining two sets of columns examine the effects on yields when the sensitivity of asset demands to interest rates are somewhat higher and lower, respectively, than the baseline.

Simulation 1: Greater Chinese Treasuries purchases Inflows from the saving glut countries are modeled as an exogenous increase in China's wealth, matched—consistent with the external surpluses being run against the United States—by an equally-sized rundown of deposits held by the United States. China's external investments rise from $\$ 1$ trillion to $\$ 3$ trillion, in the neighborhood of the increase in foreign exchange reserves of the saving glut countries from 2003 through 2006. With China's portfolio shares remaining constant at $1 / 2$ for deposits and $1 / 2$ for Treasuries (as they are assumed to be invariant with respect to interest rates), the shock leads to $\$ 1$ trillion in additional acquisitions of U.S. Treasuries and Agencies, leading the share of these securities outstanding held by China to rise to 17 percent and the share held by all foreigners to rise to nearly 30 percent.

The increased demand from China generates a decline in the equilibrium interest on Treasuries of 146 basis points. Because Treasuries and ABS are so substitutable in the portfolios of U.S. and European investors, the ABS yield (equivalently, the yield on corporate debt) declines by 168 basis points. These estimates of the effects of inflows from the GSG countries are just a little larger than those derived from the reduced-form regressions described in Section IV, which implied impacts of 110 basis points and 140 basis points, respectively. That makes sense, since as noted above, these model-based estimates assume that asset supplies are 
unchanged when interest rates decline. In reality, asset supplies might be expected to increase in response to lower rates, thus attenuating the decline in these rates. The reduced-form estimates shown in Section IV should reflect those endogenous responses, thus making them a little smaller than our model-based estimates.

Simulation 2: Greater European demands for U.S. ABS Europe did not run current account surpluses in aggregate to acquire U.S. ABS, but rather took in safe deposits from other countries to finance the ABS. We model this activity in Simulation 2a as a reduction in European demand for deposits (achieved by reducing the b0 coefficient in Europe's demand curve for deposits) coupled with an increase in their demand for ABS (achieved by increasing the b0 coefficient in Europe's demand curve for U.S. corporate bonds). This boosts the share of total U.S. corporate debt in European portfolios from 6 percent to 16 percent of European wealth, similar in magnitude to the actual $\$ 475$ billion rise in European holdings of U.S. ABS. The higher demand for ABS leads to a fall in ABS yields of 64 basis points; moreover, because Treasuries and ABS are substitutable in investor portfolios as noted above, Treasury yields decline by 49 basis points.

A number of aspects of these results are worth highlighting. First, they suggest that capital inflows from European countries into U.S. ABS generated material declines in U.S. interest rates. Second, they show how gross capital flows from Europe to the United States could have depressed yields on U.S. Treasuries and ABS, even if fully financed by other types of gross flows running from the United States to Europe. To some extent, of course, this result was "baked in the cake," since in our model the deposit interest rate is fixed. But even if the deposit rate had been endogenous in the model and rose in response to the decline in European demand for deposits, it would have had little effect on long-term Treasury and ABS yields, since deposits are not very substitutable with longer term Treasuries or ABS. This low degree of 
substitutability is well-confirmed by our estimates of asset demand equations described in Appendix A.

Notably, the effect of European acquisitions of ABS on ABS and Treasury yields is much smaller than the effect of inflows from the global saving glut countries. This in large part reflects the fact that European acquisitions of U.S. ABS, at $\$ 475$ billion, were much smaller than GSG purchases of U.S. Treasuries and Agencies. Simulation $2 b$ looks at the effect of a switch in European asset demands sufficient to match Europe's purchases of all types of U.S. corporate debt, including but not limited to ABS, during the leadup to the financial crisis. Notably, this generates declines in yields very similar to those in Simulation 1.

Simulation 3: Greater supply of U.S. ABS Third, and finally, we analyze an alternative scenario in which the U.S. housing boom is driven by factors internal to the U.S. housing and financial markets themselves rather than by foreign demand for assets. Accordingly, we present a "supply" shock, modeled as an exogenous increase in the quantity of ABS in the market. We then ask: even without an exogenous increase in foreign demand for ABS, did the willingness of European investors to absorb new supply materially reduce the extent to which yields on ABS would have risen?

In Simulation 3a, we boost the quantity of ABS by 25 percent (initially distributed on a pro rata basis to U.S. and European investors, based on their initial holdings), comparable to its actual rise during the 2003-2007 period. This leads to an increase in the share of U.S. corporate debt in total wealth at the expense of the shares of both Treasuries and deposits. As expected, this shock generates a pronounced increase in the ABS yield-by roughly 100 basis points-to persuade U.S. and European investors to absorb the excess ABS supply. Because of the substitutability between ABS and Treasuries, Treasury yields also rise, by about 70 basis points. 
In Simulation 3b, we couple the rise in the supply of ABS with the assumption that Europe will absorb none of the increase in its supply. (Specifically, we "zero out" the parameters representing the sensitivity of Europe's demand for assets to changes in interest rates, so its initial holdings of deposits, Treasuries, and ABS remain unchanged.) In this scenario, U.S. investors must absorb the entirety of the rise in ABS supply, and yields rise further, with a total increase of 141 basis points for ABS and 97 basis points for Treasuries.

This experiment highlights two key features of the global capital market in the leadup to the financial crisis. First, in the face of very large increases in the supply of these assets, European investors likely played a critical role in keeping yields on ABS and Treasuries from rising. Second, in the first experiment (Simulation 3a), Europe absorbs about 10 percent of the increase in the ABS outstanding — thus, even without a shock to Europe's asset demand curves, the increase in ABS supply leads to gross capital inflows from Europe to the United States. This suggests that at least some of the actual capital flows from Europe to the United States were pulled rather than pushed, but exactly how much is difficult to determine.

\section{Concluding Remarks}

This paper explores the channels through which foreign demand for U.S. assets may have contributed to declines in interest rates and the evolution of the U.S. housing bubble. We distinguish between two prominent sources of foreign demand: demand for Treasuries and Agencies from China, OPEC, and other emerging market Asian economies (the "global saving glut," or GSG, countries), on the one hand, and European demand for U.S. corporate debt, particularly private-label asset-backed securities (ABS), on the other. From 2003 through mid2007, GSG country acquisitions of Treasuries and Agencies totaled roughly $\$ 1$ trillion, but European acquisitions of U.S. corporate debt amounted to even more at $\$ 1.25$ trillion, of which 
nearly $\$ 500$ billion consisted of private-label ABS and some of the remainder was comprised of other structured investment products similar to ABS.

The capital flows from the GSG countries and from Europe were financed in very different ways. Acquisitions of U.S. assets from the saving glut countries represented the disposition of their sizable current account surpluses. In contrast, Europe had roughly balanced current accounts, and thus financed its acquisitions through a considerable expansion in external liabilities. Taken together, the cross border financial flows between the United States, Europe, and the GSG countries represented a global "triangular trade" in financial assets. Because Europe was financing what were, at least ex post, risky investments in the United States through, in part, issuance of safe bank deposits and sovereign debt, it was acting as a hedge fund in the global securities market, a role previously accorded mainly to the United States.

We develop a simple, stylized portfolio balance model to compare the effects on Treasury and ABS yields of capital inflows from the GSG countries and from Europe. While mainly illustrative, the model's predictions of the effects of capital flows on bond yields are quite consistent with both our own reduced-form econometric estimates and those of other analysts. The model suggests that in the years leading up to the crisis, purchases of U.S. Treasuries and Agencies by the GSG countries depressed 10-year Treasury yields on the order of 140 basis points, and the spillovers from this outcome likely lowered ABS yields by some 160 basis points. The model also indicates that, even though much of Europe's acquisitions of U.S. ABS were financed by "reverse" flows of U.S. investments into European liabilities, the effect of this exchange was to lower ABS yields by about 60 basis points and Treasury yields by 50 basis points; if we include the effect of European purchases of non-ABS U.S. corporate debt as well, these declines deepen to -160 basis points and -130 basis points, respectively. The combined 
effect of all of these inflows on U.S. interest rates would have been huge, but of course actual declines in these yields were much smaller, as the supplies of the assets to the market rose substantially as well.

Europe's acquisitions of ABS did not exclusively reflect an exogenous boost to European demand for these assets that pushed capital into the U.S. financial system. Although that was likely the case in part, as European wealth expanded rapidly, home bias diminished, and a number of regulatory and financial factors encouraged Europeans to buy U.S. ABS, at least some of these acquisitions were probably caused by the expansion of the supply of ABS, which would have pulled in capital from Europe in response to attractive returns. But even in that latter case, European investors would have played a significant role by absorbing part of the increased supply of ABS and thus containing any rise in ABS yields that otherwise would have occurred. In conclusion, it is clear that capital inflows from both the global saving glut countries and the advanced economies, especially Europe, helped depress U.S. interest rates during the middle of the past decade. A critical question not addressed in this paper is the extent to which these declines in interest rates exacerbated the housing bubble and other financial vulnerabilities. This remains a very open issue, and should represent the focus of additional research. 


\section{References}

Albertus, Jim, Carol Bertaut, and Stephanie Curcuru "Has the Crisis Changed Foreign Positions in U.S. Securities?” Federal Reserve staff working paper 2010.

Archaya, Viral and Philipp Schnabl (2010), "Do Global Banks Spread Global Imbalances? The Case of Asset-Backed Commercial Paper During the Financial Crisis of 2007-09," NBER Working Paper \#16079, June.

Arteta, Carlos, Mark Carey, Ricardo Correa, and Jason Kotter (2010), "Revenge of the Steamroller: ABCP as a Window on Risk Choices," unpublished working paper, Board of Governors of the Federal Reserve System, Division of International Finance, July 27.

Ashcraft, Adam, Paul Goldsmith-Pinkham, and James Vickery (2010), "MBS ratings and the mortgage credit boom," Federal Reserve Bank of New York, Staff Reports 449.

Baba, Naohiko, Robert N. McCauley, and Srichander Ramaswamy (2009), "US Dollar Money Market Funds and Non-US Banks," BIS Quarterly Review, March.

Beltran, Daniel, Maxwell Kretchmer, Jaime Marquez, and Charles Thomas (2011), "Foreign Official Holdings of U.S. Treasuries and U.S. Interest Rates: A Lens on the 'Savings Glut'," Working Paper, Federal Reserve Board, May.

Beltran, Daniel, Laurie Pounder, and Charles Thomas (2008), "Foreign Exposure to AssetBacked Securities of U.S. Origin,” International Finance Discussion Paper No. 939, August.

Bernanke, Ben S. (2005), "The Global Saving Glut and the U.S. Current Account Deficit." The Sandburg Lecture, Virginia Association of Economists, Richmond, VA, March 10.

Bernanke, Ben S. (2007), "Global Imbalances: Recent Developments and Prospects.” The Bundesbank Lecture, Berlin, Germany, September 11.

Bernanke, Ben S. (2009), "Financial Reform to Address Systemic Risk," Speech at Council of Foreign Relations, Washington, DC, March 10.

Bernanke, Ben S., Carol Bertaut, Laurie Pounder DeMarco, and Steven Kamin (2011), "International Capital Flows and the Return to Safe Assets in the United States, 2003-2007," Banque de France Financial Stability Review, February, pp. 13-26.

Bertaut, C.C. and Linda S. Kole (2004), "What Makes Investors Over or Underweight? Explaining Investor Appetites for Foreign Equities," International Finance Discussion Paper No. 819 , September.

Bertaut, Carol, William Griever, and Ralph Tryon (2006), "Understanding U.S. Cross-Border Securities Data," Board of Governors of the Federal Reserve System, Federal Reserve Bulletin, May. 
Bini Smaghi, Lorenzo (2008), "The Financial Crisis and Global Imbalances: Two Sides of the Same Coin," Speech at the Asia Europe Economic Forum, Beijing, December 9.

Blanchard, Olivier, Francesco Giavazzi, and Filipa Sa (2005). "The U.S. Current Account and the Dollar, "NBER Working Paper Series 11137. Cambridge, Mass.: National Bureau of Economic Research, February.

Borio, Claudio and Piti Diyatat (2010), "Global Imbalances and the Financial Crisis: Understanding the Role of International Finance," Asian Economic Policy Review, 5, pp. 198216.

Brender, Anton, and Florence Pisani (2010). Global Imbalances and the Collapse of Globalized Finance. Brussels: Centre for European Policy Studies.

Caballero, Ricardo J., Emmanuel Farhi, and Pierre-Olivier Gourinchas (2008). "An Equilibrium Model of 'Global Imbalances' and Low Interest Rates," American Economic Review, vol. 98 (1), pp. 358-93.

Caballero, Ricardo, Emmanuel Farhi, and Pierre-Olivier Gourinchas (2009), "Financial Crash, Commodity Prices, and Global Imbalances," Working paper, November.

Caballero, Ricardo (2009), “The 'Other' Imbalance and the Financial Crisis," NBER Working Paper \#15636, January.

Clarida, Richard H. (2005). "Japan, China, and the U.S. Current Account Deficit," Cato Journal, vol. 25 (1), pp. 111-14.

Cooper, Richard N. (2005). "Living with Global Imbalances: A Contrarian View," Peterson Institute for International Economics Policy Brief PB05-3. Washington: Peterson Institute for International Economics, November.

Coval, Joshua, Jakub Jurek and Erik Stafford (2009), "The Economics of Structured Finance," Journal of Economic Perspectives, vol 23(1), pp.3-25.

D’ Amico, Stefania and Thomas B. Kamin (2011), "Flow and Stock Effects of Large-Scale Treasury Purchases," Board of Governors of the Federal Reserve System, Finance and Economics Discussion Series, April (revised, original draft September 2010).

Demyanyk, Yuliya and Otto Van Hemert (2009), "Understanding the Subprime Mortgage Crisis," The Review of Financial Studies, vol 24(6) June, pp. 1848-1880.

Diamond, Douglas W. and Raghuram G. Rajan (2009), "The Credit Crisis: Conjectures about Causes and Remedies," American Economic Review, vol. 99(2), pp.606-610, May.

Dokko, Jane, Brian Doyle, Michael T. Kiley, Jinill Kim, Shane Sherlund, Jae Sim, and Skander Van den Heuvel (2009). "Monetary Policy and the Housing Bubble," Finance and Economics 
Discussion Series 2009-49. Washington: Board of Governors of the Federal Reserve System, December.

Dooley, Michael P., David Folkerts-Landau, and Peter Garber (2003), “An Essay on the Revived Bretton Woods System," NBER Working Paper 9971, September.

Ehrmann, Michael, Marcel Fratzscher, and Arnaud Mehle. "What has made the current financial crisis truly global?" working paper, May 2009.

Gagnon, Joseph, Matthew Raskin, Julioe Remarche, and Brian Sack (2010), "Large-Scale Asset Purchases by the Federal Reserve: Did They Work?" Federal Reserve Bank of New York Staff Report No. 441, March.

Gerardi, Kristopher, Andreas Lehnert, Shane Sherlund, and Paul Willen (2008). "Making Sense of the Subprime Crises," in Brookings Papers on Economic Activity, vol. 2 (Fall). Washington: Brookings Institution Press, pp. 69-145.

Gleaser, Edward L., Joshua D. Gottlieb, and Joseph Gyourko (2010), “Can Cheap Credit Explain the Housing Boom?" NBER Working Paper 16230, July.

Greenspan, Alan (2005). "Monetary Policy Report to the Congress," statement before the Committee on Banking, Housing, and Urban Affairs, U.S. Senate, February 16.

Gruber, Joseph and Steven B. Kamin (2007), "Explaining the Global Pattern of Current Account Imbalances," Journal of International Money and Finance, vol. 26 (June), pp. 500-522.

Gruber, Joseph and Steven B. Kamin (2009), "Do Differences in Financial Development Explain the Global Pattern of Current Account Imbalances?" Review of International Economics, vol. 17 (September), pp. 667-688.

Hamilton, James D. and Jing (Cynthia) Wu. "The Effectiveness of Alternative Monetary Policy Tools in a Zero Lower Bound Environment," working paper, February 2011.

Hubbard, R. Glenn. (2005). “A Paradox of Interest,” Wall Street Journal, June 23.

Jagannathan, Ravi, Mudit Kapoor and Ernst Schaumburg (2009), "Why Are We in a Recession? The Financial Crisis is the Symptom no the Disease!" Working paper, August.

Johnson, Karen, "Gross or Net International Financial Flows: Understanding the Financial Crisis," Council on Foreign Relations Working Paper, July 2009.

Ju, J. and Wei, S-J. (2006), “A solution to two paradoxes of international capital flows,” IMF Working Paper WP/06/178.

Kamin, Steven B. and Laurie Pounder DeMarco (2010), "How Did a Domestic Housing Slump Turn into a Global Financial Crisis?” International Finance Discussion Paper No. 994, January. 
Kashyap, Anil K., Raghuram G. Rajan, and Jeremy C. Stein (2008), "Rethinking Capital Regulation," in Maintaining Stability in a Changing Financial System, Federal Reserve Bank of Kansas City, 431-471.

Mayer, Christopher, Karen Pence, and Shane M. Sherlund (2009). "The Rise in Mortgage Defaults," Journal of Economic Perspectives, vol. 23 (Winter), pp. 27-50.

McGuire, Patrick and Goetz von Peter (2009), "The US Dollar Shortage in Global Banking," BIS Quarterly Review, March.

Mendoza, Enrique G., Vincenzo Quadrini, and Jose-Victor Rios-Rull (2007). "Financial Integration, Financial Deepness, and Global Imbalances," NBER Working Paper Series 12909. Cambridge, Mass.: National Bureau of Economic Research, February.

Obstfeld, Maurice and Kenneth Rogoff (2009), "Global Imbalances and the Financial Crisis: Products of Common Causes," Paper presented at the Federal Reserve Bank of San Francisco Asia Economic Policy Conference, Santa Barbara, CA October 18-20.

Rajan, Raghuram (2010), Fault Lines, Princeton University Press, Princeton, N.J.

Rose, Andrew and Mark Spiegel (2009): "Cross-Country Causes and Consequences of the 2008 Crisis: International Linkages and American Exposure," NBER Working Paper 15358, September 2009.

Rudebusch, Glenn D., Eric T. Swanson, and Tao Wu (2006), “The Bond-Yield 'Conundrum' from a Macro-Finance Perspective," Federal Reserve Bank of San Francisco Working Paper 2006-16, May.

Sa, Filipa, Pascal Towbin, and Tomasz Wieladek (2011), "Low interest rates and housing booms: the role of capital inflows, monetary policy, and financial innovation," Bank of England Working Paper No. 411, February 2011.

Taylor, John B. (2009), “The Financial Crisis and the Policy Responses: An Empirical Analysis of What Went Wrong," NBER Working Paper 14631, January.

Warnock, Frank and Veronica Warnock (2009): "International Capital Flows and U.S. Interest Rates. Journal of International Money and Finance, vol. 28, pp. 903-919. 


\section{Appendix A: Estimation of Portfolio Balance Model}

As noted in the text, the model consists of three demand equations for assets $\mathrm{A}$ as a share of total wealth $\mathrm{W}$, reproduced below. $b$ stands for bank deposits, $t$ for Treasury securities, and $c$ for corporate debt, including ABS.

$$
\begin{gathered}
\frac{A_{b}}{W}=b_{0 b}+\beta_{b b} r_{b}-\beta_{b t} r_{t}-\beta_{b c} r_{c} \\
\frac{A_{t}}{W}=b_{0 t}-\beta_{t b} r_{b}+\beta_{t t} r_{t}-\beta_{t c} r_{c} \\
\frac{A_{c}}{W}=b_{0 c}-\beta_{c b} r_{b}-\beta_{c t} r_{t}+\beta_{c c} r_{c}
\end{gathered}
$$

One feature of asset demand equations of this type is that an equal increase in all three interest rates $r$ (leaving differentials between these interest rates unchanged) should leave asset demands unchanged as well. Accordingly, the various parameters for each country must obey

$$
\begin{gathered}
\beta_{b b}-\beta_{b t}-\beta_{b c}=0 \\
\beta_{t t}-\beta_{t b}-\beta_{t c}=0 \\
\beta_{c c}-\beta_{c t}-\beta_{c b}=0
\end{gathered}
$$

Based on these restrictions, we can re-write the demand equations in A1 in terms of the spread of Treasury yields over bank deposit interest rates and the spread of corporate debt yields over deposit rates:

$$
\begin{gathered}
\frac{A_{b}}{W}=b_{0 b}-\beta_{b t}\left(r_{t}-r_{b}\right)-\beta_{b c}\left(r_{c}-r_{b}\right) \\
\frac{A_{t}}{W}=b_{0 t}+\beta_{t t}\left(r_{t}-r_{b}\right)-\beta_{t c}\left(r_{c}-r_{b}\right) \\
\frac{A_{c}}{W}=b_{0 c}-\beta_{c t}\left(r_{t}-r_{b}\right)+\beta_{c c}\left(r_{c}-r_{b}\right)
\end{gathered}
$$

Jumping ahead to the solution of the model, we note that as written, A3 represents a system of three equations and two unknowns, the Treasury spread $r_{t}-r_{b}$ and the corporate bond spread $r_{c}-$ $\mathrm{r}_{\mathrm{b}}$. However, this system is not over-determined. Because all three asset-shares $\frac{A_{b}}{W}, \frac{A_{t}}{W}$, and $\frac{A_{C}}{W}$ must sum to unity, this implies a set of cross-equation restrictions on the parameters, shown in equations (A4) below. Those restrictions, in turn, imply that the three equations are linearly dependent, so that only two of the three equations are needed to solve for the two endogenous spreads. In practice, we use the second two equations, the demand curves for Treasuries and corporate debt, to solve the model. 


$$
\begin{gathered}
\beta_{b b}-\beta_{t b}-\beta_{c b}=0 \\
\beta_{t t}-\beta_{b t}-\beta_{c t}=0 \\
\beta_{c c}-\beta_{t c}-\beta_{b c}=0
\end{gathered}
$$

Before solving the model, however, we obtain estimates of the $\beta$ coefficients from the following empirical equations:

$$
\begin{array}{r}
\frac{M_{U S, t}}{W_{U S, t}}=f\left(\left(R_{10, t}-R_{C D, t}\right),\left(R_{C o r p, t}-R_{C D, t}\right), \frac{N G D P_{U S, t}}{W_{U S, t}}\right) \\
\left(R_{10, t}-R_{C D, t}\right)=f\left(\frac{T_{t}}{W_{t}},\left(R_{C o r p, t}-R_{C D, t}\right), \widehat{Y_{t}^{e}}, \pi_{t+10}^{e}, B D E F_{t}\right) \\
\left(R_{C o r p, t}-R_{C D, t}\right)=f\left(\frac{C_{t}}{W_{t}},\left(R_{10, t}-R_{C D, t}\right), \widehat{Y_{t}^{e}}, \pi_{t+10}^{e}, B D E F_{t}\right)
\end{array}
$$

$R_{10, t}: 10$-year U.S. Treasury yield, nominal

$R_{\text {Corp }, t}:$ AAA corporate bond yield, nominal

$R_{C D, t}:$ 6-month CD rate, nominal

$\widehat{Y_{t}^{e}}:$ expected GDP growth (blue chip)

$\pi_{t+10}^{e}$ : expected inflation rate (10-year ahead Michigan survey)

$B D E F_{t}$ : federal budget deficit as a share of GDP

$M_{U S, t}:$ U.S. M2 money stock

$M_{t}$ : U.S. M2 money stock + euro area M2 money stock + U.K. M4 money stock

$T_{t}$ : Marketable Treasury bonds - U.S. debt held by the Federal Reserve

$C_{t}$ : U.S. corporate bonds outstanding

$W_{U S, t}: M_{U S, t}+T_{t}+C_{t}$

$W_{t}: M_{t}+T_{t}+C_{t}$

$N G D P_{U S, t}:$ nominal U.S. GDP

A number of aspects of these equations should be highlighted. First, although we do not use the equation for deposits demand when we solve the model, it is useful to estimate the equation to assess whether the estimated parameters are consistent with those in the other two equations. As a proxy for bank deposits, we use the somewhat broader M2 money stock, which includes currency, another important element in investor portfolios. We also use exclusively U.S. variables for this equation; given our assumption of identical demand curves in the United States and Europe, either country (or both) could have been used for estimation.

Second, the second and third equations in our system are inverted so that the endogenous variables of interest - the spreads of Treasury and corporate yields over CD rates-appear as the dependent variables. They are likely to be more endogenous than the supply of Treasuries, which arguably is determined by the path of fiscal deficits, although this argument may not apply to the supply of U.S. corporate bonds. (Partly to keep the variable as exogenous as possible, we 
use the supply of Treasuries alone, rather than the supply of Treasuries and Agencies, as an explanatory variable.) Note that for these two equations, portfolio shares are specified as asset supplies divided by the combined wealth of the United States and Europe, since yields on U.S. Treasuries and corporate debt reflect the demand from both U.S. and European investors.

Third, we have introduced a number of control variables to better identify the effects of the variables of interest in our system. In the money demand equation, nominal GDP is an obvious determinant. Similarly, expected inflation and GDP growth, as well as the budget deficit, seem likely to influence Treasury and corporate bond yields in addition to asset supplies.

The three equations were estimated using two-stage least squares on quarterly data for the period 1980 to 2007 . The control variables along with lags of the endogenous variables were used as instruments. Results of the estimation are shown in Table A1. By and large, the estimates are quite reasonable. In the Treasury spreads and corporate spreads equations, the coefficients on the asset shares and the alternative spreads are positive and statistically significant in most cases. In the money demand equation, the coefficients on the two spread variables are significant but quite small, suggesting that the demand for money is not very responsive to longer-term yields, while the coefficient on nominal GDP is positive and significant, as expected.

The table below translates the coefficient estimates into their implied parameter values, along with re-calculated z-statistics, for the original model shown in equation A1 above. The results for the Treasuries and corporate bond demands indicate that these two assets are relatively substitutable in investor portfolios, as their responsiveness to Treasury and corporate bond yields are broadly similar in magnitude, whereas neither is very substitutable with bank deposits. (The coefficient of .10 on the CD rate in the corporate bonds equation has a counter-intuitive sign, but is quite small.) This observation is confirmed by the very small coefficients on all three asset returns in the deposit demand equation, suggesting that deposit demands are relatively invariant with respect to rates of return.

\begin{tabular}{|c|c|c|c|}
\hline $\begin{array}{c}\text { Derivative of asset } \\
\text { demand with respect } \\
\text { to rate of return }\end{array}$ & $\begin{array}{c}\text { 6-month CD interest } \\
\text { rate }\end{array}$ & $\begin{array}{c}\text { 10-year Treasury } \\
\text { yield }\end{array}$ & $\begin{array}{c}\text { AAA Corporate } \\
\text { bond yield }\end{array}$ \\
\hline Deposit/Wealth & .01 & -.06 & .05 \\
& $(3.38)$ & $(-4.88)$ & $(4.95)$ \\
\hline Treasuries/Wealth & -.08 & .36 & -.27 \\
& $(-2.47)$ & $(2.54)$ & $(-2.52)$ \\
\hline $\begin{array}{c}\text { Corporate } \\
\text { bonds/Wealth }\end{array}$ & .09 & -.54 & .45 \\
\hline
\end{tabular}

Another finding highlighted by these results is that the demand for corporate bonds appears more sensitive to Treasury yields than is the demand for Treasuries with respect to corporate bond yields. This seems consistent with the results of the reduced-form regressions shown in Table 2, which indicate that the foreign official purchases of Treasuries and Agencies depress AAA corporate bond yields even more than they depress yields on Treasuries themselves. 
As discussed in the main text, these estimated parameters are used to model the asset demands of U.S. and European investors. Consistent with past behavior, the demands of the global saving glut countries are assumed to be invariant with respect to interest rates. 


\section{Appendix B: Selected Data Sources}

\section{Sources for total amounts of U.S. securities outstanding}

Total amounts of U.S. securities outstanding are taken from the U.S. Flow of Funds accounts levels (L) tables, available on the Federal Reserve Board website at this link: http://www.federalreserve.gov/releases/z1/default.htm

Total Treasury securities: Table L.2, line 4

Total Agency securities: Table L.3, lines 3 plus 4

Total financial corporate debt: Table L.3, line 5

Total non-financial corporate: Table L.2, lines 4, 6, and 7

Total private-label $\mathrm{ABS}^{18}$ : Table L.3, line 19

\section{Estimates of foreign holdings and acquisitions of U.S. securities, by country}

Estimated holdings of U.S. securities, broken down by investing country, are based on the annual Treasury International Capital (TIC) surveys of foreign portfolio holdings of U.S. securities. These comprehensive surveys record holdings of U.S. securities by country of holder as of endJune for various years. Survey reports are available on the Treasury website at http://www.treasury.gov/resource-center/data-chart-center/tic/Pages/fpis.aspx

To adjust the end-June securities holdings recorded by the surveys to create estimates as of yearend, we use the Bertaut-Tryon (2007) data, which adjusts for financial center transactions bias and valuation changes. These estimates, as well as a detailed methodology of their construction, are available at: http://www.federalreserve.gov/pubs/ifdp/2007/910/default.htm

Further, by aggregating countries to look at Europe as a whole, we bypass much of the custodial bias inherent in these data. Custodial bias occurs when financial institutions hold securities in custodial accounts for end-investors that live in other countries. Bertaut, Griever, and Tryon (2006) investigate which countries are the major custodial centers for U.S. securities (including Belgium and Luxembourg), and which countries have undercounts of securities holdings (including France, Italy, the U.K. and the Channel Islands), - suggesting that their residents' investments are custodied elsewhere. Since other Europeans are likely the owners of much of the custodial holdings in Belgium and Luxembourg, looking at Europe as a whole significantly reduces the bias.

For estimates of cumulated foreign net purchases of U.S. securities in Figures 2, 3, and 4 we also use the Bertaut-Tryon data base. ${ }^{19}$ In addition to estimated monthly holdings, this data base provides estimates of monthly changes in holdings, decomposed into identified adjusted net flows (flows are adjusted primarily for repayments of ABS), monthly valuation changes, and the

\footnotetext{
${ }^{18}$ In this appendix, ABS refers broadly to all asset-backed securities including mortgage-backed securities.

${ }^{19}$ We use the Bertaut-Tryon data, which corrects for financial center bias in the estimated net purchases by country, instead of the as-reported TIC net purchases data available on the Treasury website because the financial center distortions are particularly important for the countries we consider.
} 
residual "gap" required to reconcile the reported transactions data with the annual survey holdings. We construct cumulated net purchases by country as the sum of the monthly adjusted net flows plus the monthly "gap" to generate estimates of net purchases that are corrected for financial center bias.

We are able to implement the methodology above for purchases of Treasury securities, agency securities, and total corporate debt. We then decompose further our estimates of net purchases of corporate debt by country into purchases of ABS, financial corporate debt, and nonfinancial corporate debt using the relative shares of these types of corporate debt as reported in the detailed data from the annual surveys.

\section{Adjusted foreign official net purchases and holdings of Treasury and agency securities}

Although the TIC system collects data separately for foreign official transactions and other foreign investor transactions in U.S. securities, the published TIC statistics underrepresent actual foreign official purchases because they only classify as official those transactions that occur directly between a U.S. counter-party and a foreign official investor. If an official investor acquires a U.S. security through a foreign intermediary, the initial purchase by the foreign intermediary would be recorded in the TIC but the subsequent acquisition by the official investor would not be recorded because it is not a U.S. cross-border transaction. As a result, the annual surveys of foreign holdings of U.S. securities typically show that foreign official holdings are substantially higher than would be estimated by cumulating net transactions since the previous survey and applying valuation changes (see Bertaut, Griever, and Tryon (2006) for further discussion.)

Because the monthly TIC data are known to understate official transactions, some analysts and researchers look instead at movements in the weekly custody holdings for official and international accounts at the Federal Reserve Bank of New York (FRBNY) as reported in memo lines to the Federal Reserve release H.4.1. However, these data are also imperfect and incomplete for several reasons. First, they account for only those official securities held at FRBNY, which serves as a custodian for only about three-fourths of all Treasuries held domestically for foreign official investors. Second, the definition of "official" is slightly different, as the memo lines include changes in holdings for some international accounts that are not classified as foreign official in the published TIC statistics. Third, changes in FRBNY's holdings of Agency securities for official investors are recorded at original face value, which can overstate both purchases and sales (or maturities) of seasoned Agency MBS, because the value of the holdings have not been adjusted to account for repayments of principal. Finally, not all changes in FRBNY custody holdings reflect foreign official acquisitions or sales. Official investors will at times move securities between FRBNY and other domestic custodians, and thus a change in FRBNY holdings may simply reflect a custodian shift.

To adjust monthly net purchases of long-term Treasuries and Agencies, we compare the monthly changes in the (confidential) information on custody holdings of long-term Treasuries and agencies for selected official investors at the Federal Reserve Bank of New York with transactions in these securities as reported in the TIC system for years 2002 forward. When the 
changes in holdings for these selected accounts are larger than reported in the TIC system and we do not believe these changes reflect custodial shifts, we augment the TIC official transactions to account for these larger increases. We also adjust the TIC transactions for estimated principal repayments on foreign official holdings of Agency MBS.

Following the Bertaut-Tryon methodology, we then decompose the change in total foreign official holdings of long-term Treasuries and Agencies into the contributions accounted for by adjusted net flows, valuation changes, and the residual monthly gap. Note that some monthly gap still remains: our ability to adjust monthly transactions is still incomplete as we cannot account for unrecorded acquisitions that are placed with other domestic custodians. However, compared to the original Bertaut-Tryon foreign official series, the recorded "gap" on the survey date is notably smaller: for June 2006, for example, we reduce the gap for official holdings of Treasuries from $\$ 130$ billion to $\$ 22$ billion, and for long-term agencies from $\$ 149$ billion to $\$ 81$ billion. We include a file (ticdata.liabilities.foiadj.csv) of the new underlying monthly estimates of total foreign official holdings of long-term Treasuries, Agencies, corporate bonds, and equities, the adjusted monthly net flows in each of these security types, monthly estimated valuation changes, and the residual monthly gaps, for December 1984 through the most recent annual survey (June 2010). These adjusted estimates of foreign official holdings form the basis of our measures of foreign holdings of Treasuries and Agencies in our regression models.

\section{European cross-border financial flows shown in Figure 6}

We proxy Europe's cross-border financial flows over this period by summing the flows for the euro area and the U.K., using their balance of payments (BOP) and international investment positions (IIP) data. For the euro area, these are available in the Monthly Bulletin table 7.3 and related dataset: http://sdw.ecb.europa.eu/reports.do?node $=100000210$. For the United Kingdom, these are available in the annual Pink Book and associated data set: http://www.statistics.gov.uk/statbase/product.asp?vlnk=1140. These sources provide data on three types of cross-border investment: direct investment, portfolio investment (equity and debt securities), and other investment (banking and other transactions). Summing the flows of the euro area and the U.K. would overstate their combined net flows with the rest of the world because it would include their flows to each other. To correct this, we subtract the flows between the two economies, primarily using the geographical breakdowns of their IIPs. ${ }^{20}$ All flows and positions are converted to U.S. dollars on a quarterly basis.

Importantly, these sources do not disaggregate flows of debt securities by type, distinctions that are important to understanding the build-up of risk before the crisis. They also do not separate "other investment" into categories that are useful for thinking about the crisis, such as interbank transactions versus transactions with non-banks. Accordingly, we disaggregate these categories using a variety of other sources; we provide a brief overview below of our methodology. Further detail on our estimation procedures is available upon request.

\footnotetext{
${ }^{20}$ We use separate geographical breakdowns for the three broad types of investment; for "other investment," we are able to estimate flows separately for bank and non-bank positions.
} 


\section{Disaggregating debt securities}

We disaggregate Europe's external claims and liabilities in the form of debt securities into ABS, other financial corporate, non-financial corporate, and sovereign debt using different methods for claims and liabilities because of differences in data availability. For claims, we start with Europe's acquisitions of U.S. debt securities of each type, which are available from the Treasury International Capital (TIC) system. For Europe's claims on other countries besides the United States, we draw on the country distribution of euro area and U.K. claims in the form of debt securities found in the IMF's Coordinated Portfolio Investment Survey (CPIS), and assume that European investors acquired a similar portfolio of debt securities from each country as U.S. investors acquired from that country (again using TIC data to estimate the composition of U.S. acquisitions).

For external liabilities, the U.K. data differentiate between sovereign debt, bank debt and nonbank debt. We assume that, in addition to bank debt, one-quarter of U.K. non-bank debt is issued by financial firms and the remainder is by non-financial firms. For the euro area, data on external liabilities in the form of sovereign debt are available for recent years; we estimate foreign acquisitions of sovereign debt for the earlier period based on euro area sovereign debt issuance. ${ }^{21}$ Corporate debt liabilities of the euro area (excluding ABS) are split into financial and non-financial categories by assuming investors from all countries acquired a portfolio of European corporate debt similar to that acquired by U.S. investors (based on TIC data). Finally, our estimates of foreign holdings of European ABS, combining the euro area and the United Kingdom, are primarily based on data from the European Securitization Forum (ESF) on gross issuance of ABS and primary distribution of ABS abroad; as the resulting estimates are particularly tenuous, the U.S. acquisitions of European ABS (shown in the TIC data) provide a lower bound.

\section{Disaggregating Banking and Other Transactions}

In Figure 6, we present two broad categories of banking and other transactions. The first is "net interbank transactions and deposits," which represents the net of external claims and liabilities of the following three types of transactions: 1) interbank transactions; 2) repurchase agreements (repos) between or among banks and other financial firms, such as securities dealers; and 3) deposits by non-bank residents (where deposits abroad by European residents are a claim and deposits in European banks from non-bank foreigners are a liability). The second category is "net loans to non-banks and other," which represents the net of external claims and liabilities of the following two types of transactions: 1) loans to non-banks (where loans to non-banks abroad — made either by banks or non-bank firms — are a claim and loans from abroad to European non-banks are a liability); and 2) miscellaneous other (such as increased currency liabilities of the ECB to foreigners).

Of the five transaction types identified in the above paragraph, only two, deposits by non-bank residents and miscellaneous other, are clearly identified in the BOP or IIP data. The amounts for the other types are estimated using several sources, including primarily: 1) additional breakdowns that are provided in the euro area and U.K. BOP data; 2) BIS locational data, which

\footnotetext{
${ }^{21}$ We adjust for the fact that foreign acquisitions of euro area sovereign debt tended to grow faster than sovereign debt issuance and confirmed our figures with acquisitions of euro-denominated reserve assets in the Currency Composition of Official Foreign Exchange Reserves (COFER) data.
} 
splits banks' cross-border positions into those with other banks and those with non-banks; and 3) aggregate balance sheet data published by the euro area and the U.K. for banks, other financial firms, and non-financial firms. 


\section{Figure 1}

\section{Composition of U.S. Hxternal @abilities}

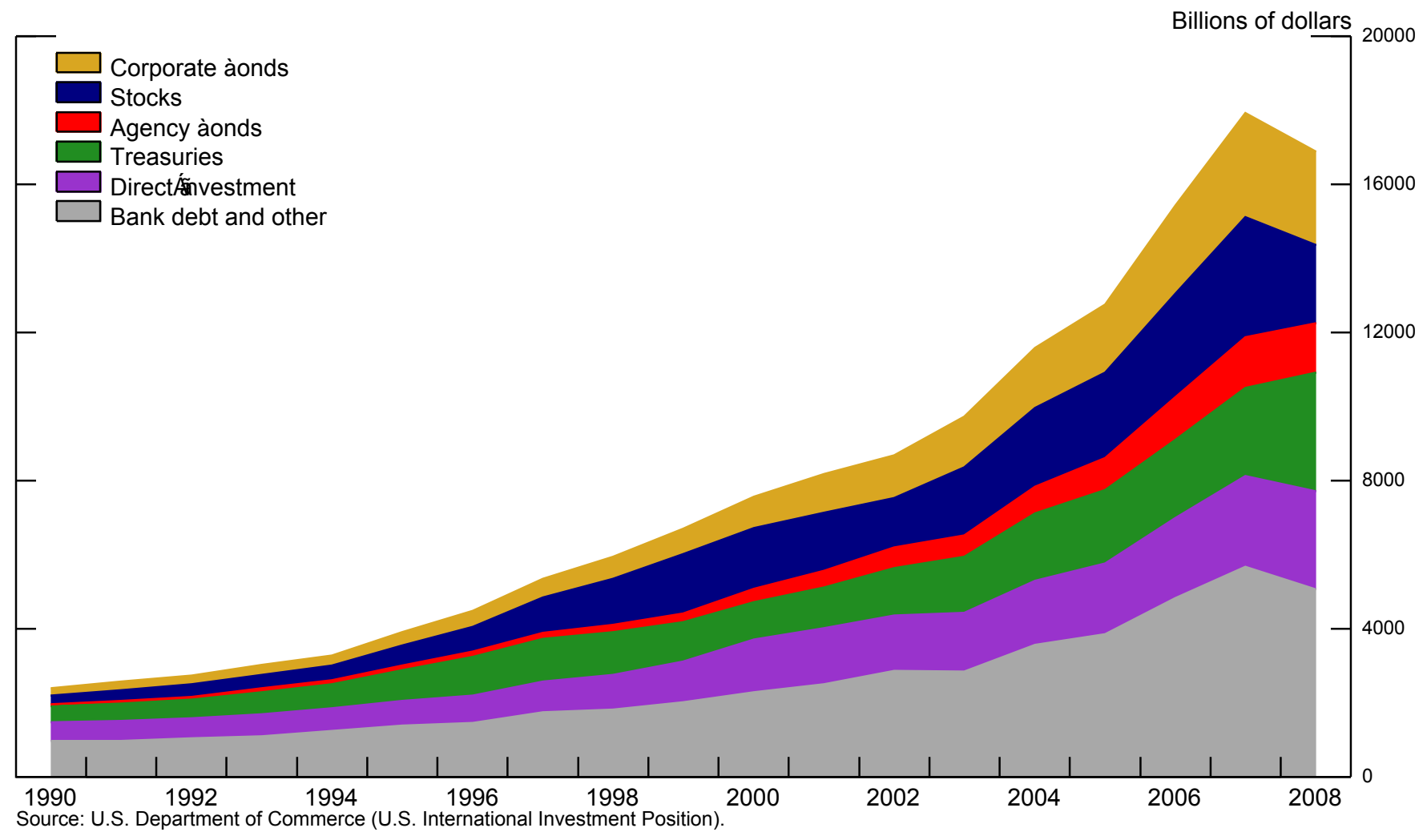




\section{Figure 2}

Foreign inflows into U.S. debt securities in lead-up to the financial crisis

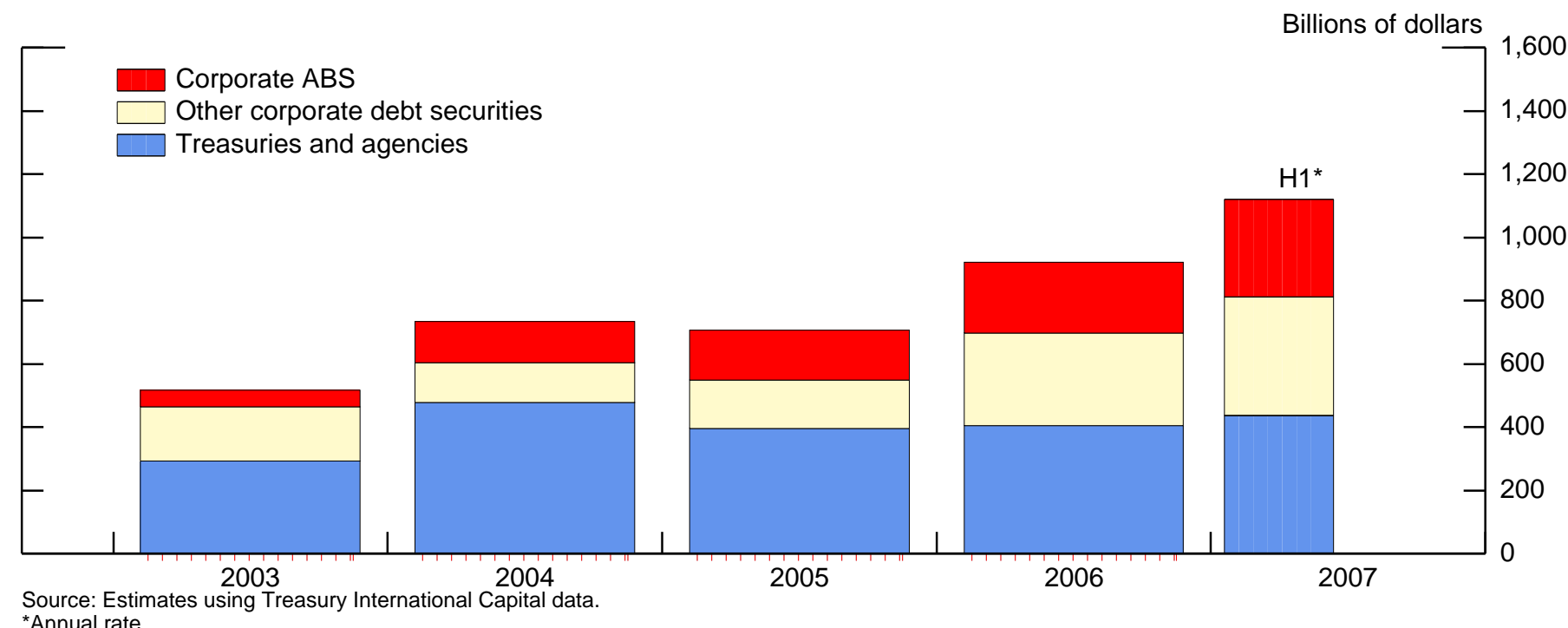
*Annual rate. 
Figure 3

Cumulated foreign inflows into U.S. debt securities

Jan. 2003 to June 2007

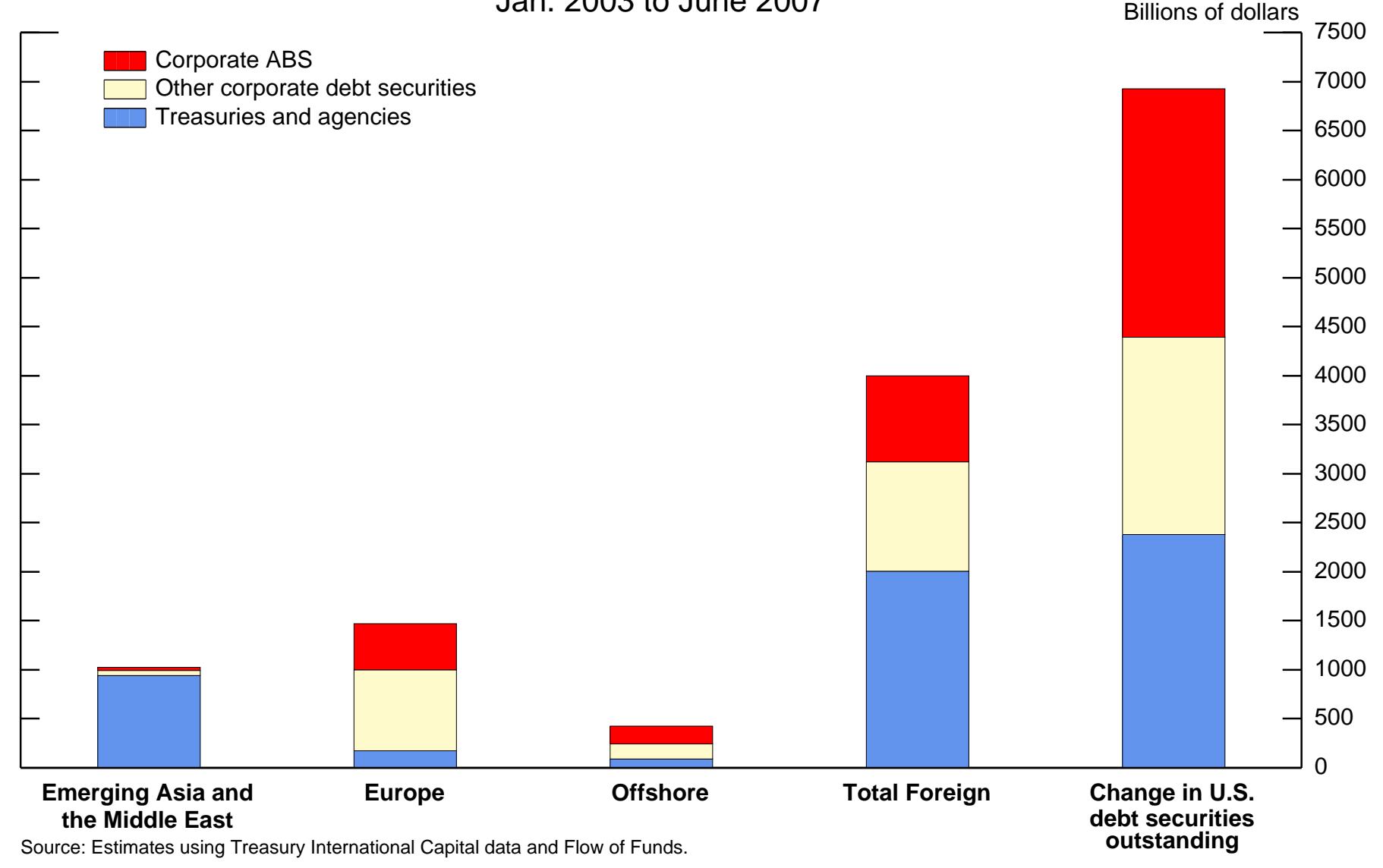




\section{Figure 4}

\section{Current account surpluses and financial acquisitions of certain surplus regions}

2003 to 2007

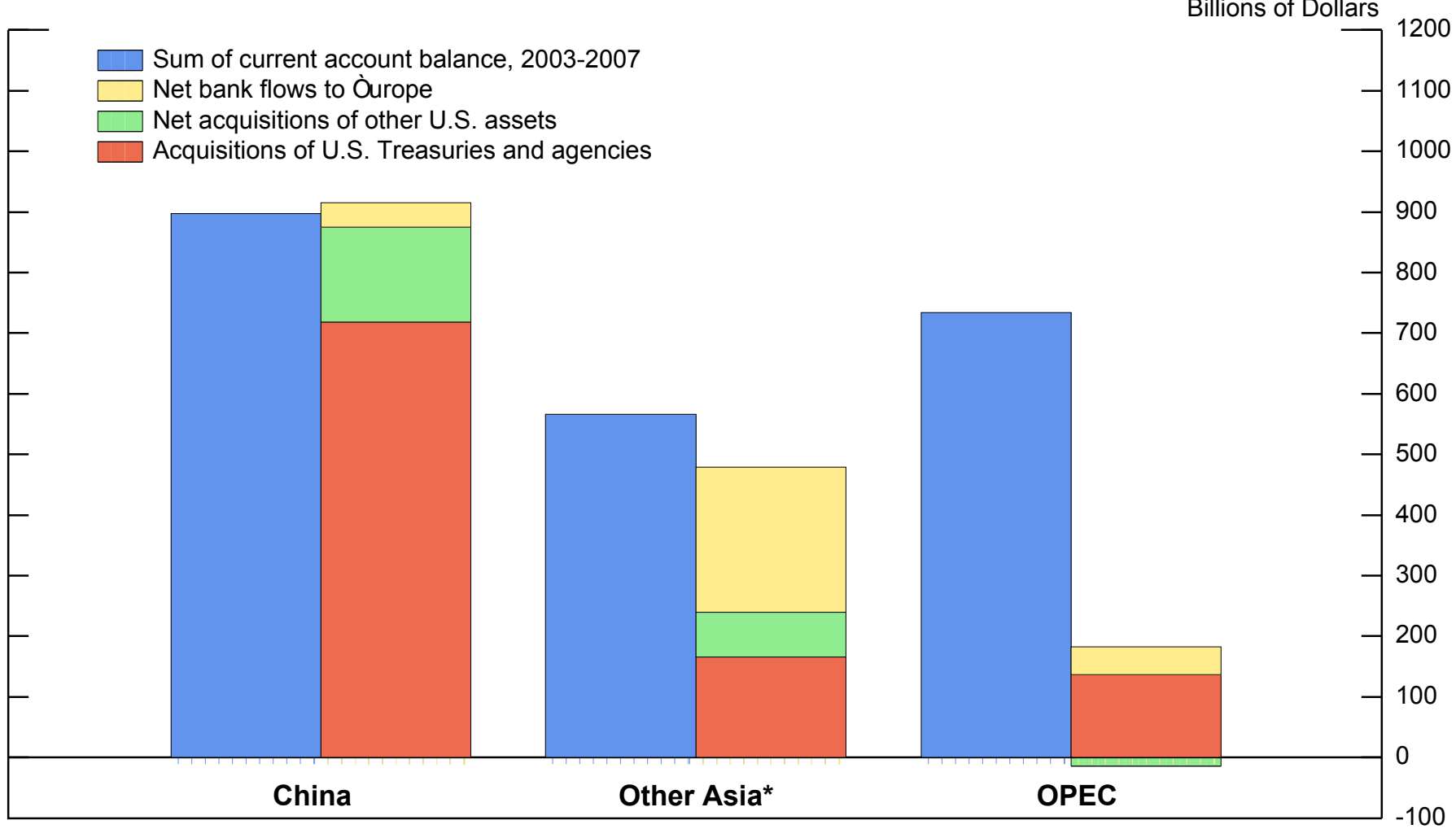

Sources: Haver Analytics, Bureau of Economic Analysis, Treasury International Capital and Bank for International Settlements.

*Other Asia excludes Japan. 


\section{Figure 5}

\section{Europe's gross international claims and liabilities}

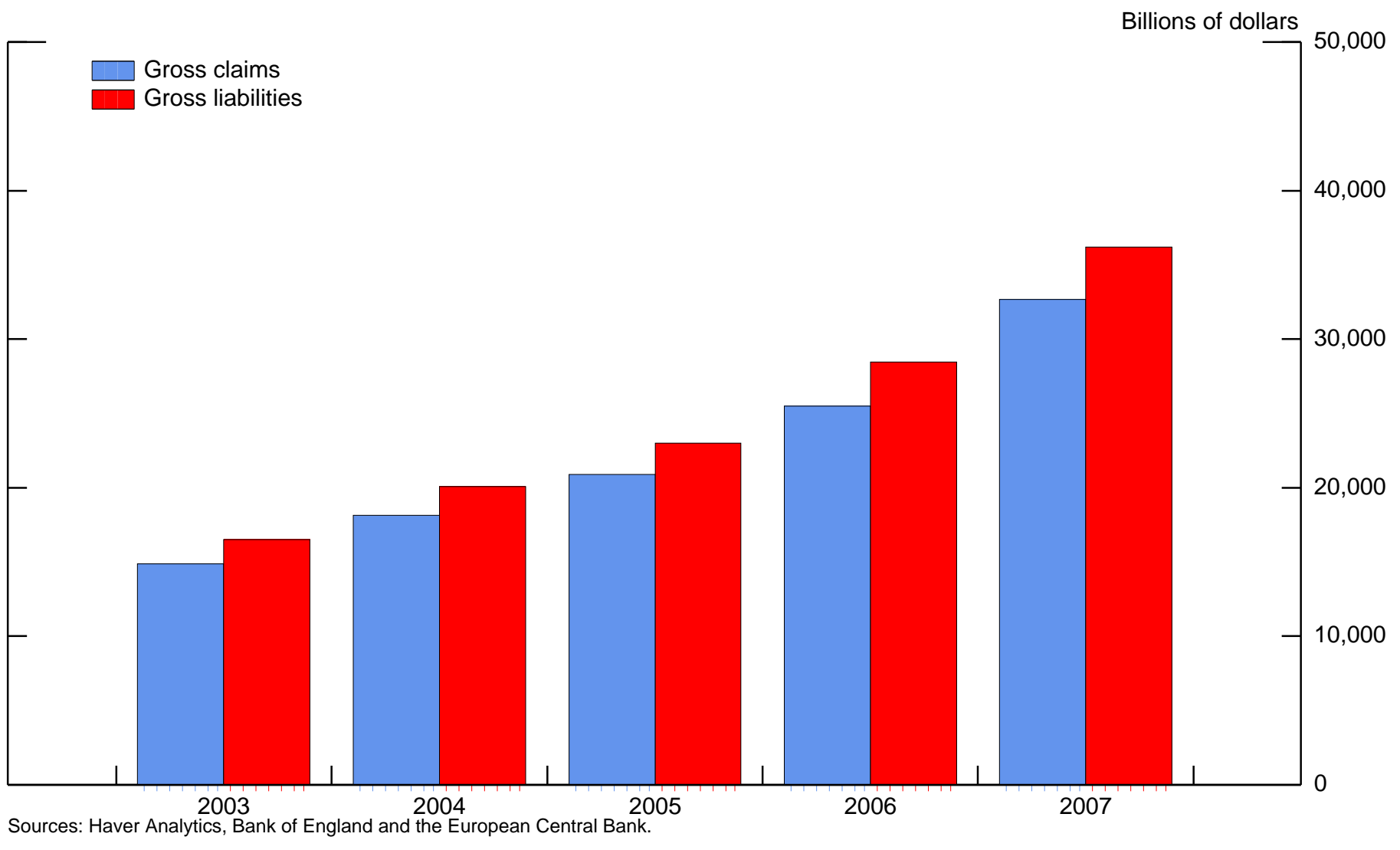




\section{Figure 6}

\section{Cumulated European cross-border financial flows}

Jan. 2003 to June 2007

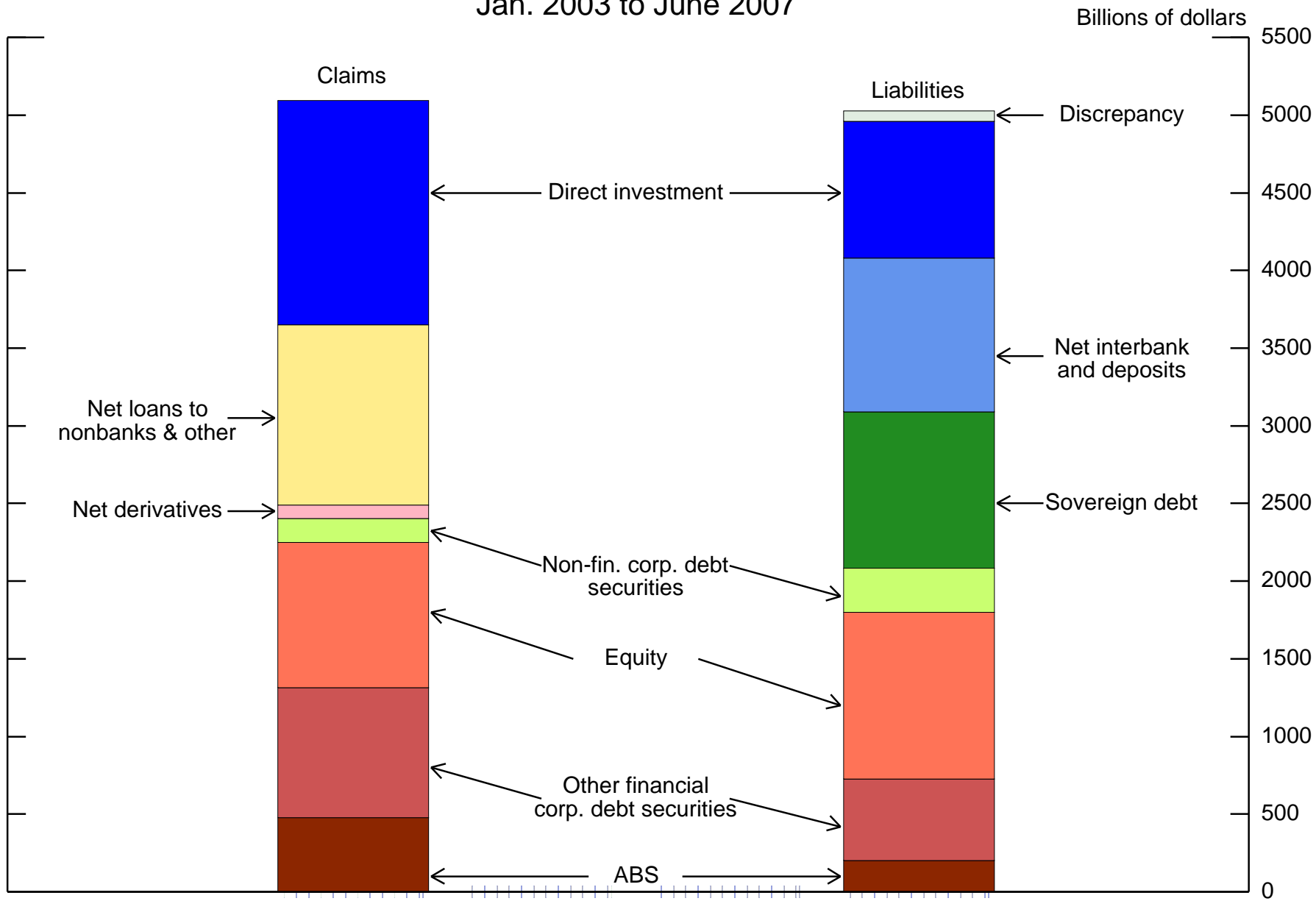

Source: Estimates based on euro area and U.K. financial accounts and data from the BIS. 


\section{Figure 7}

Geographical breakdown of European cross-border financial flows in debt securities 2003 to 2007

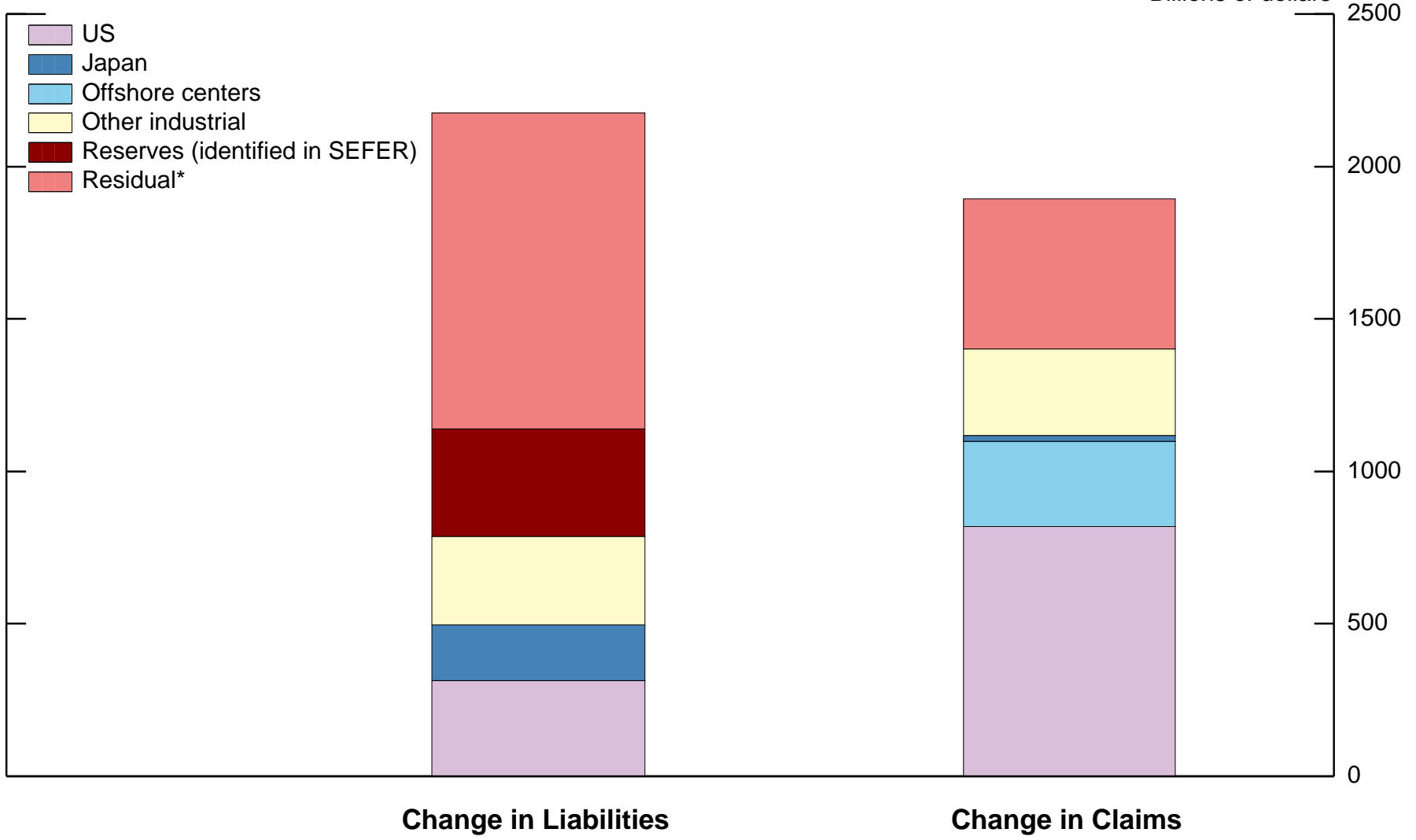

${ }^{*}$ Residual liabilities are to EMEs and Offshore centers; residual claims are mainly on EMEs (especially eastern Europe).

'Europe' is defined as euro area plus U.K., and excludes cross-holdings.

Source: Estimates using IMF's Coordinated Portfolio Investment Survey and Treasury International Capital. 


\section{Figure 8}

\section{European* and U.S. financial wealth}

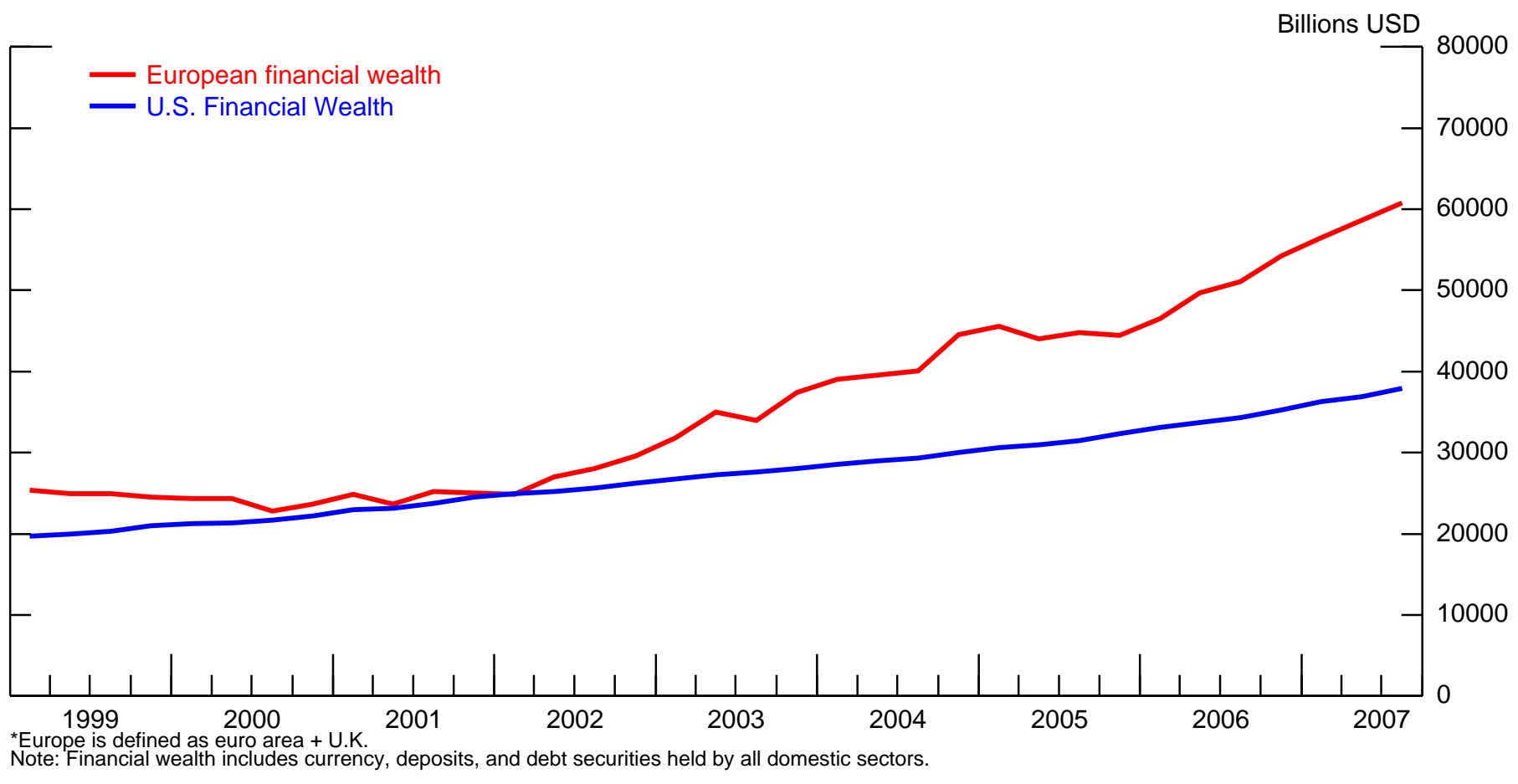

Figure 9

\section{European* and U.S. financial wealth as a percent of GDP}

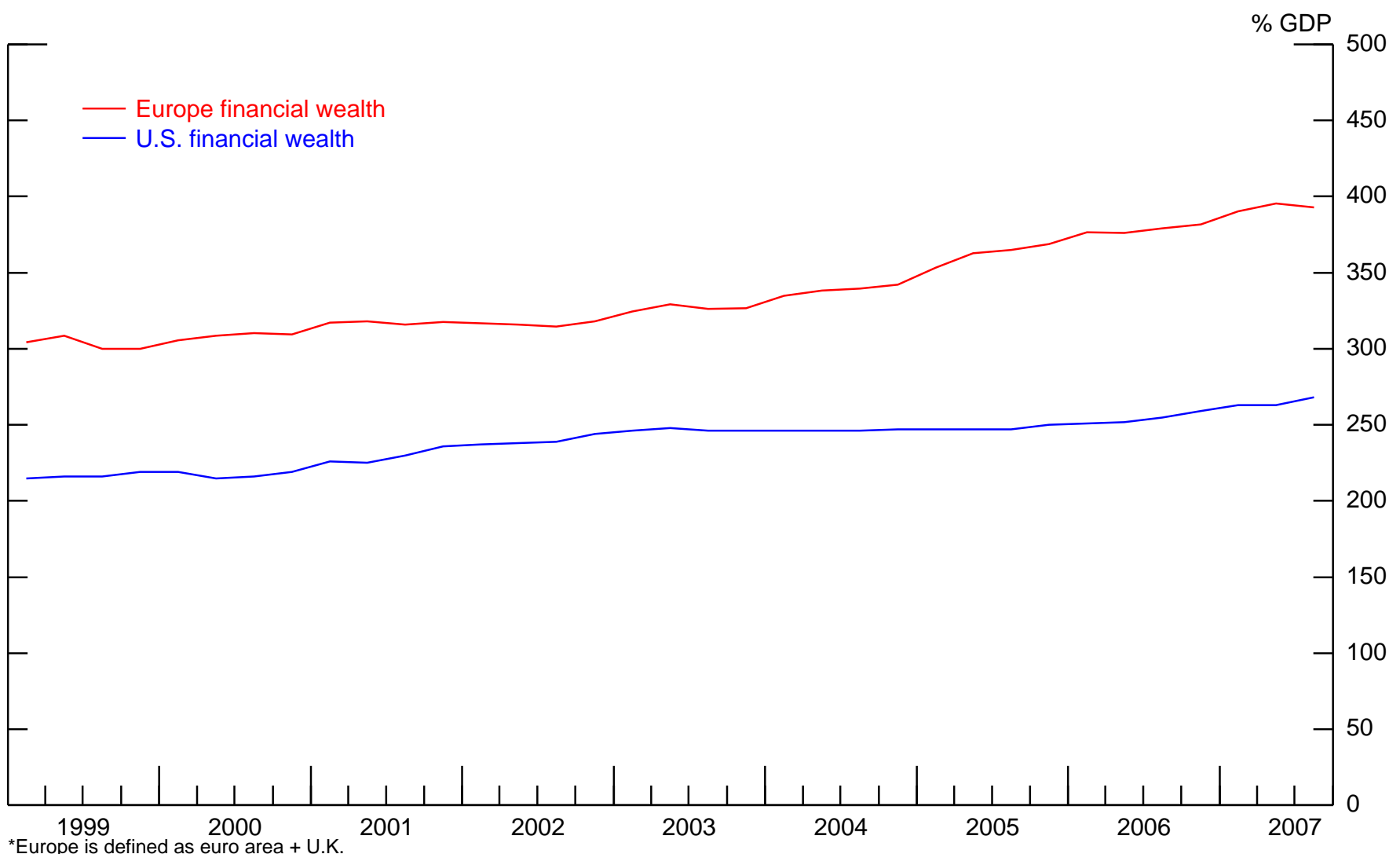

Note: Financial wealth includes currency, deposits, and debt securities held by all domestic sectors. 
Figure 10

\section{European portfolio weights in U.S. and foreign bonds}

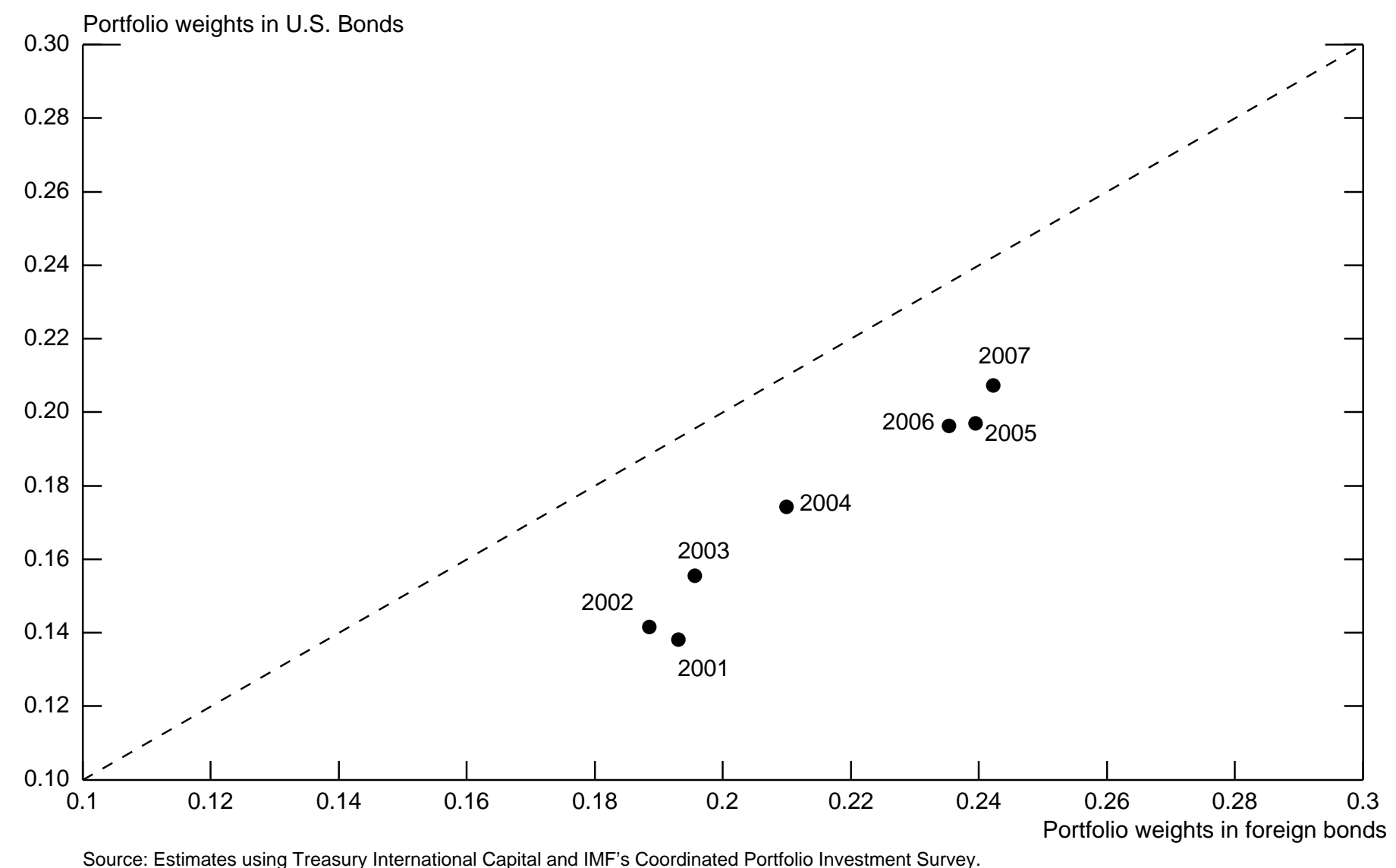




\section{Figure 11}

\section{European holdings of foreign long-term debt securities}

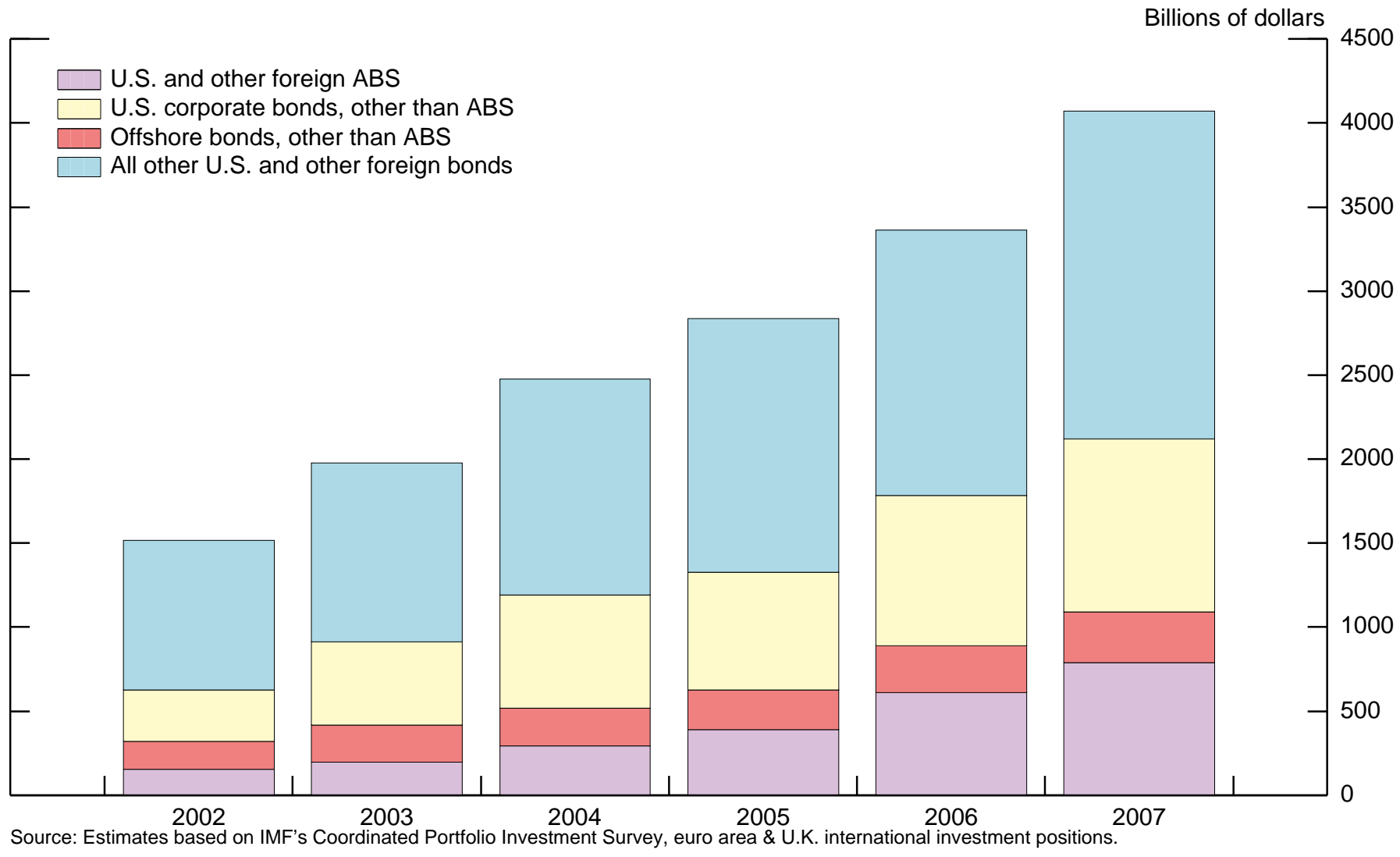


Figure 12

Decrease in home bias arising from ABS cross-border investment

Dec. 2003 to Dec. 2007

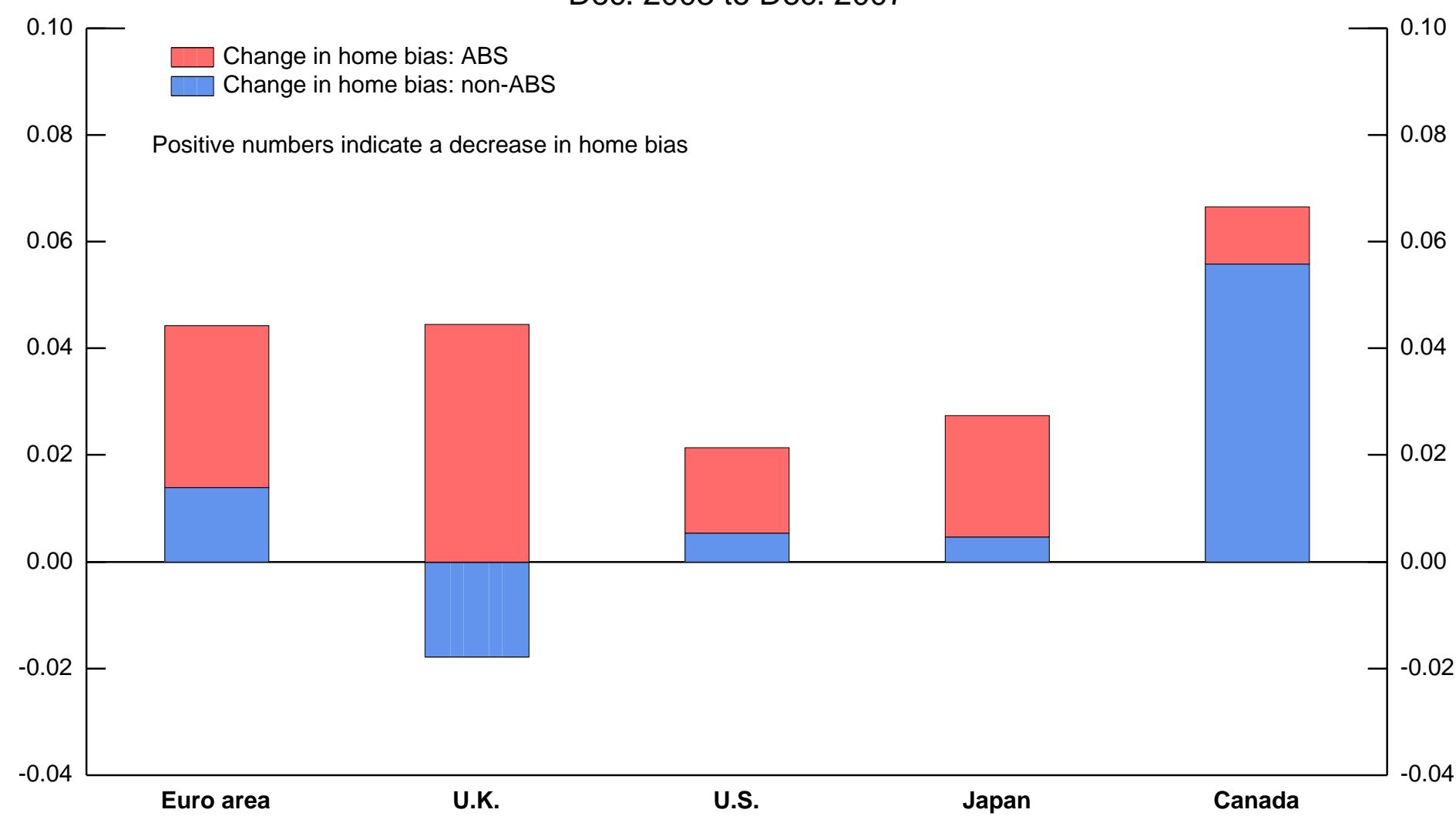

Source: Estimates using IMF's Coordinated Portfolio Investment Survey and Treasury International Capital. 


\section{Figure 13}

\section{ABS and MBS Issuance}

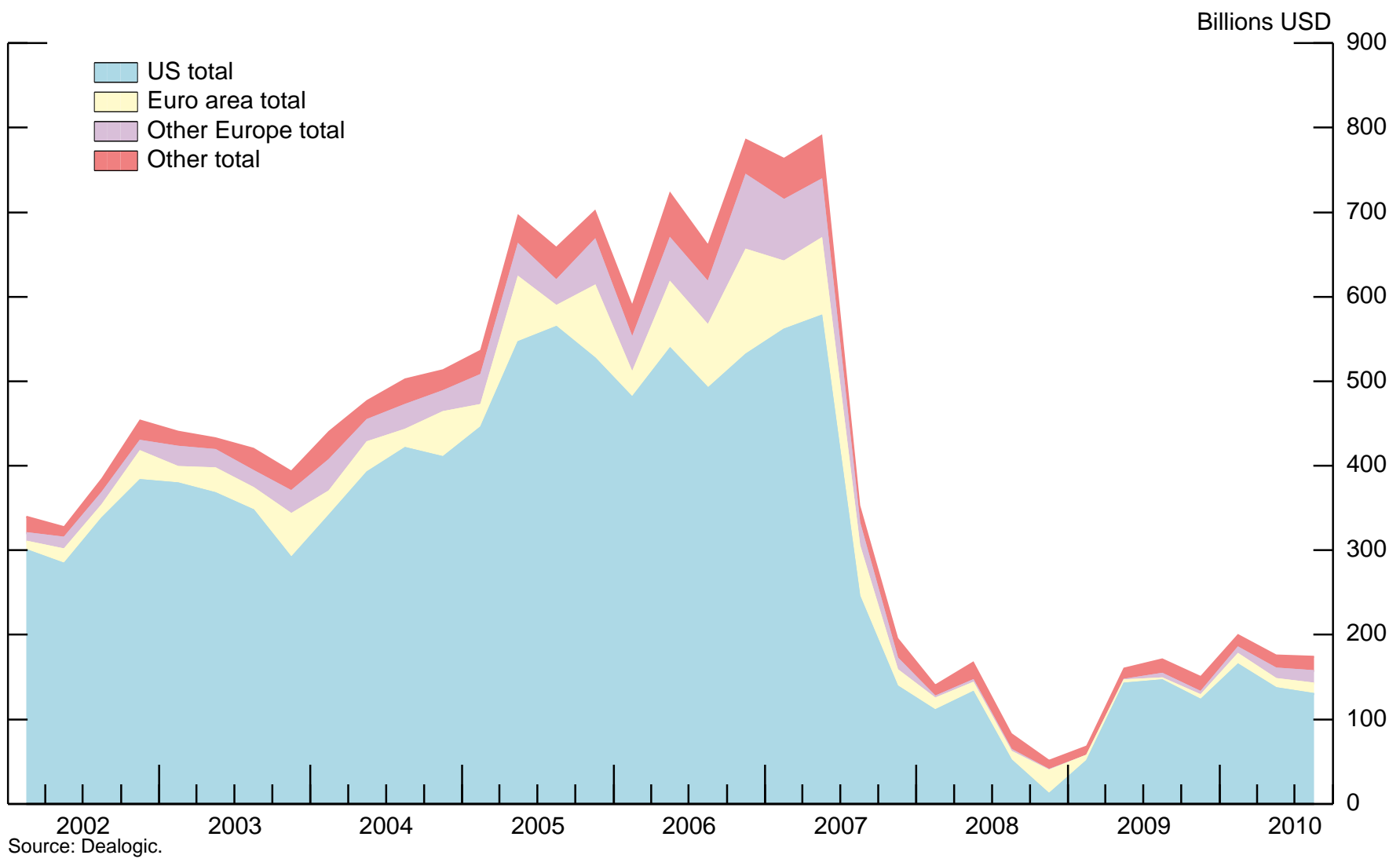


Figure 14: Holdings of U.S. securities outstanding Total Outstanding
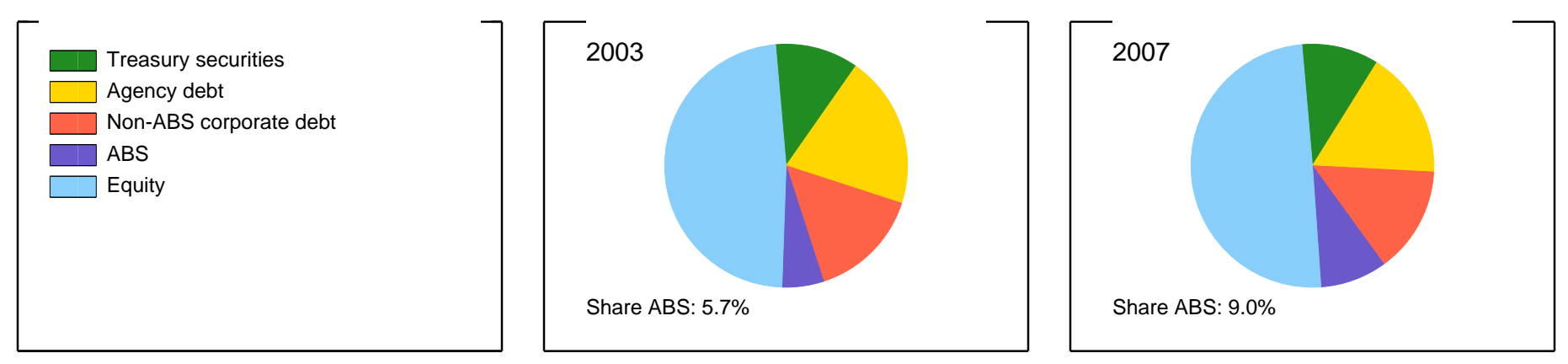

\section{Held by global saving glut countries}
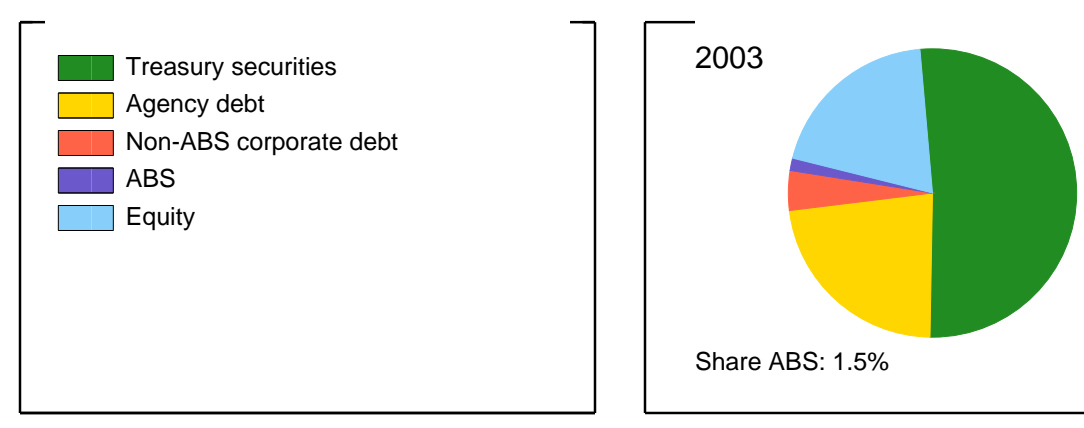

Share ABS: $1.5 \%$

\section{Held by Europe}
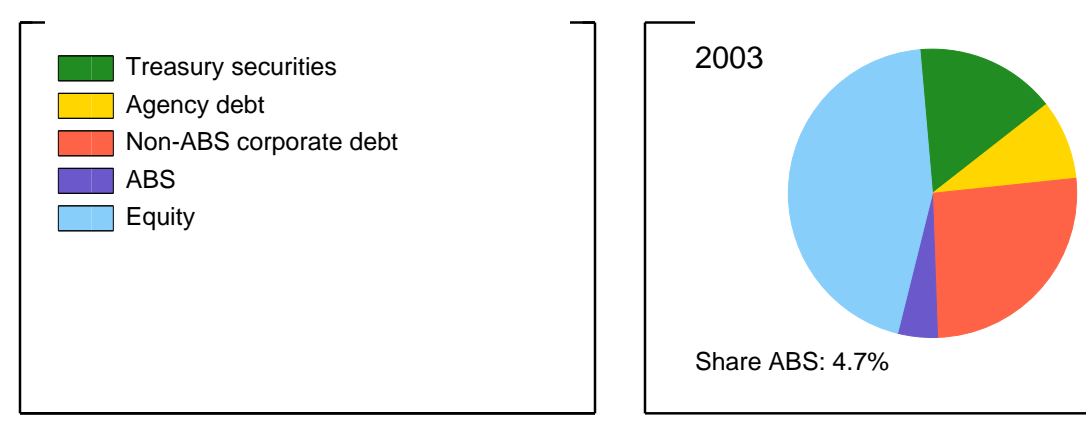

Share ABS: $4.7 \%$

\section{Held by U.S. residents}

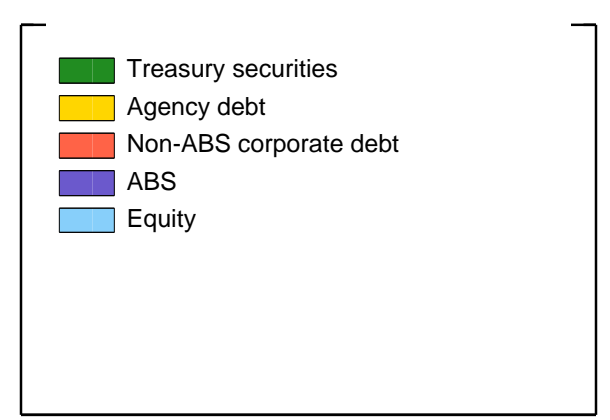

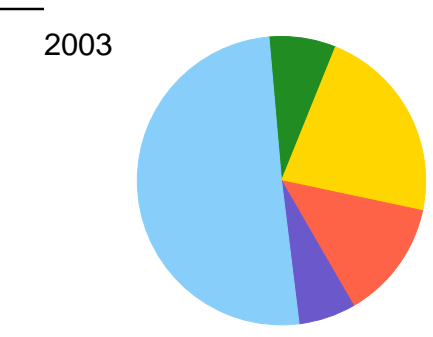

Share ABS: $6.1 \%$

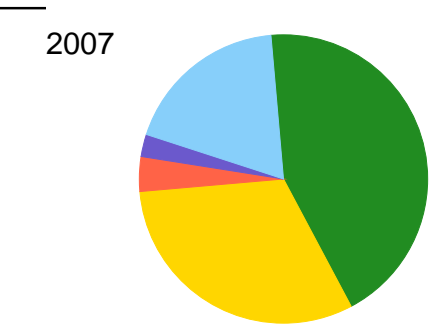

Share ABS: $2.4 \%$

2007

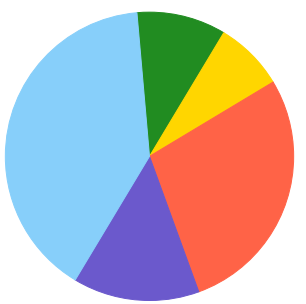

Share ABS: $14.0 \%$

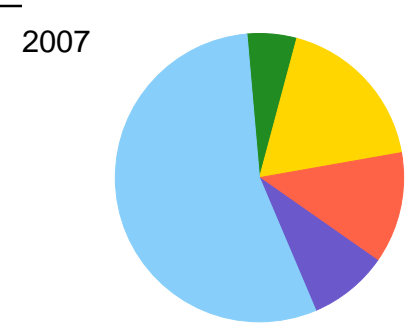

Share ABS: $8.9 \%$ 
Figure 15

Policy Targets and Corporate Yields

Monetary Policy Targets

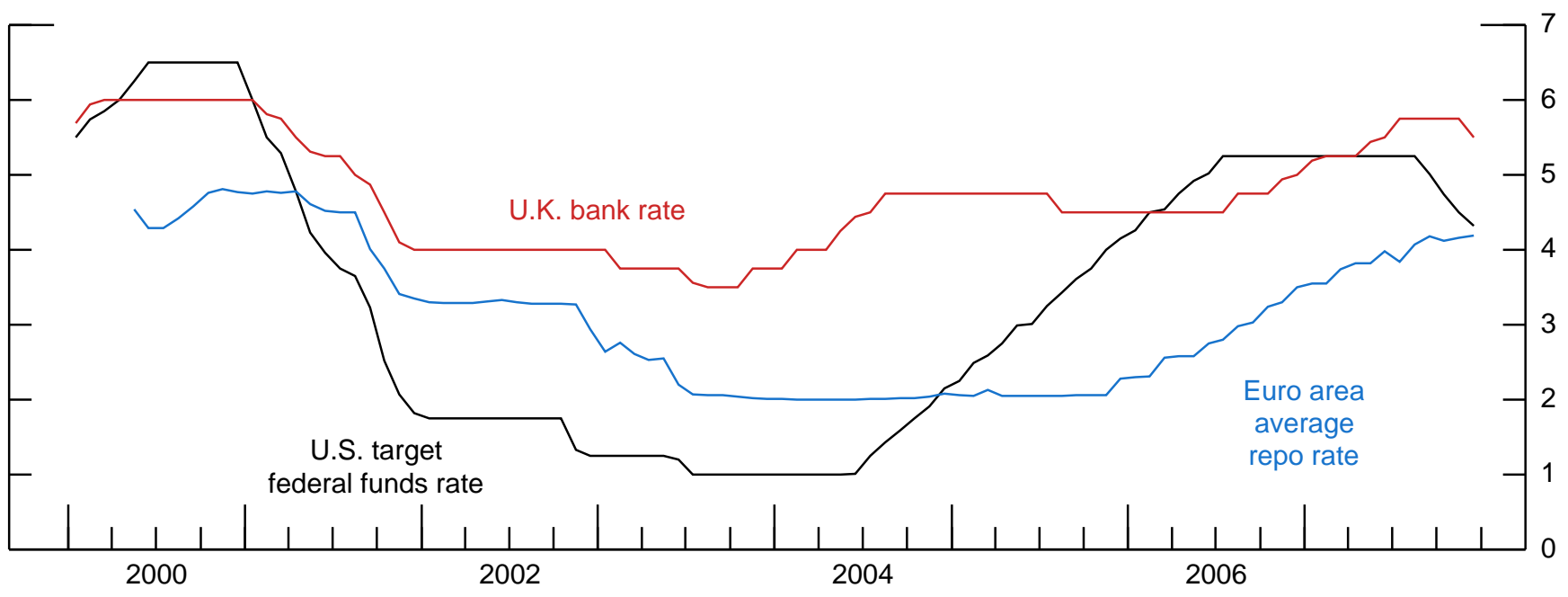

United States

Euro Area
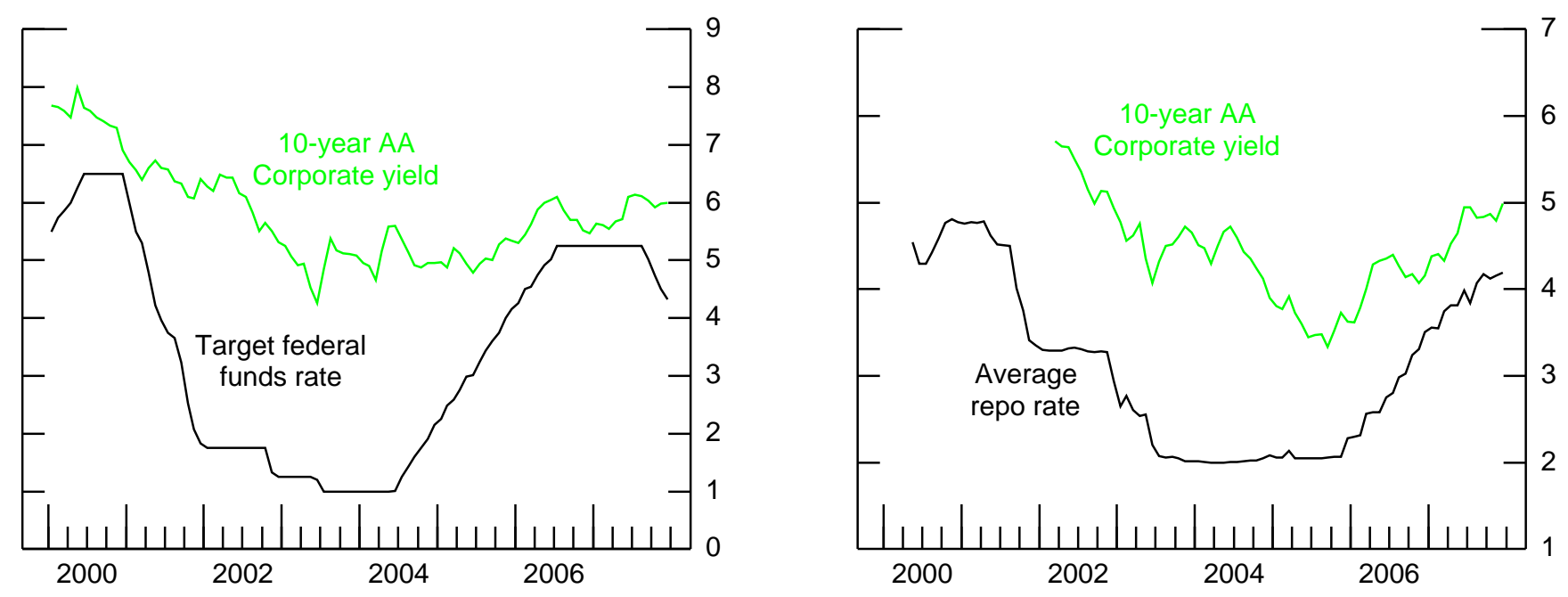

United Kingdom

Spread between Corporate Yield and Policy Rate

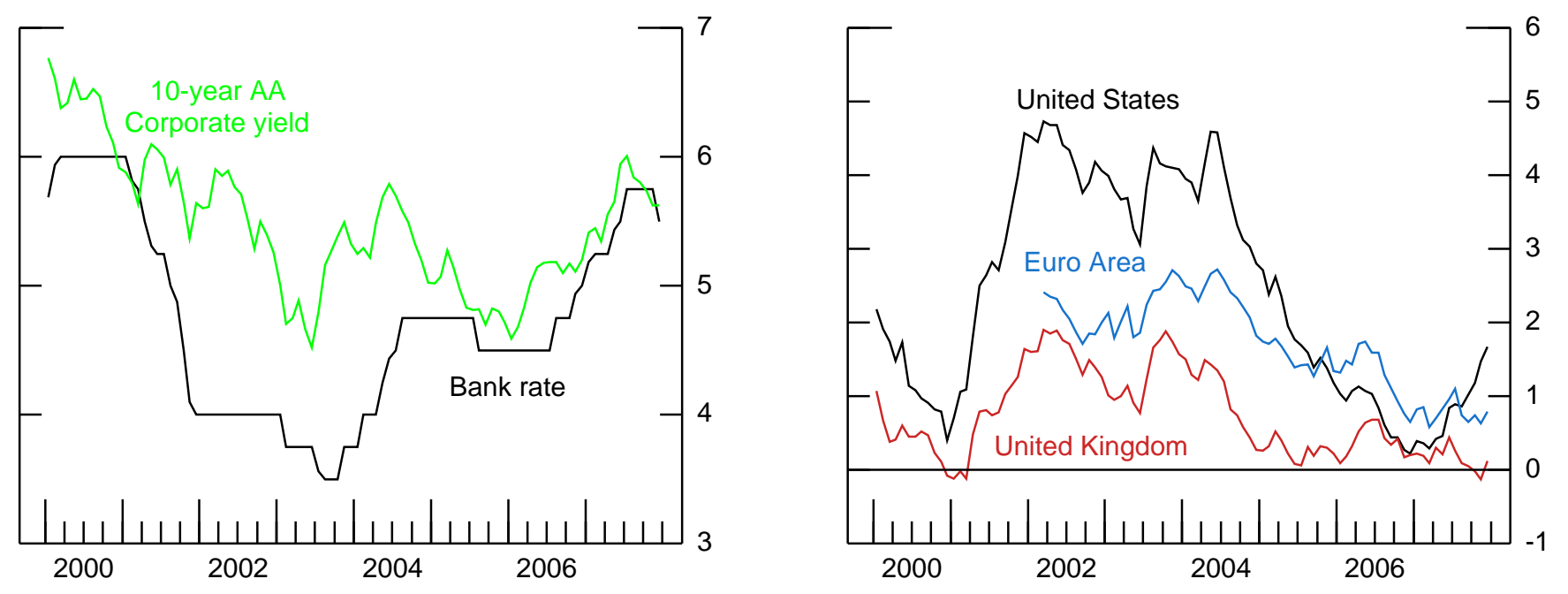


Figure 16

\section{Selected long-term rates}

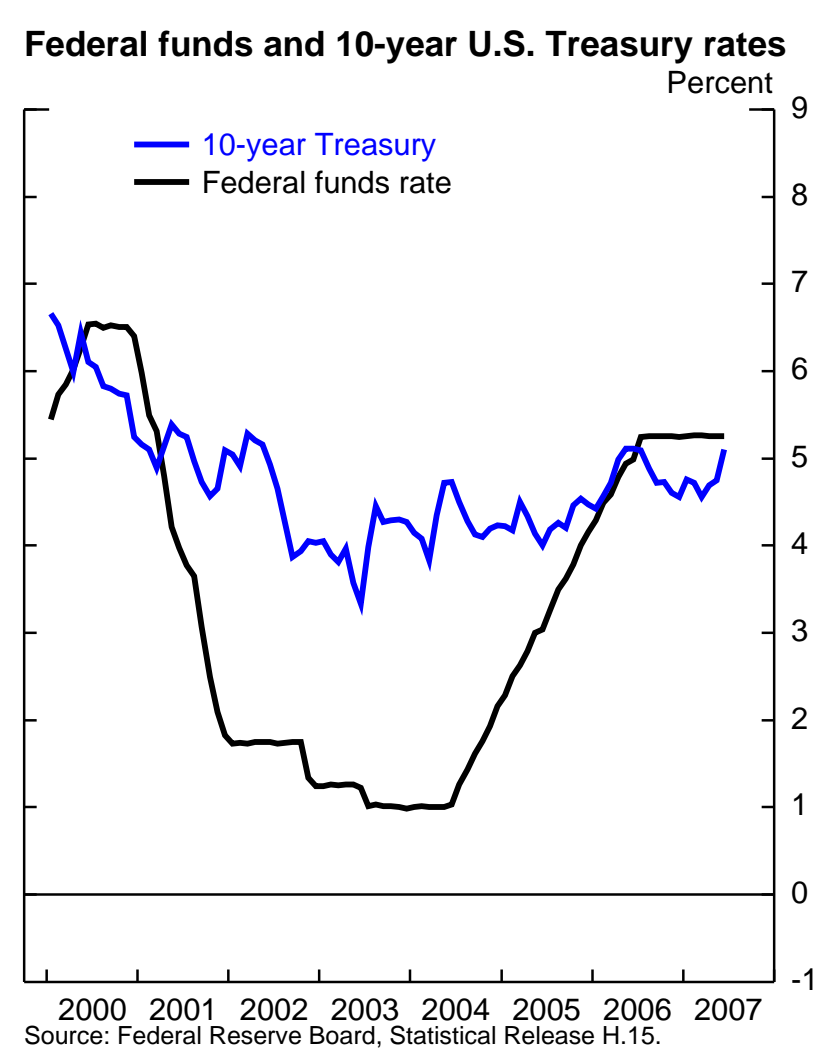

10-year U.S. Treasury and AAA corporate yields, and spread

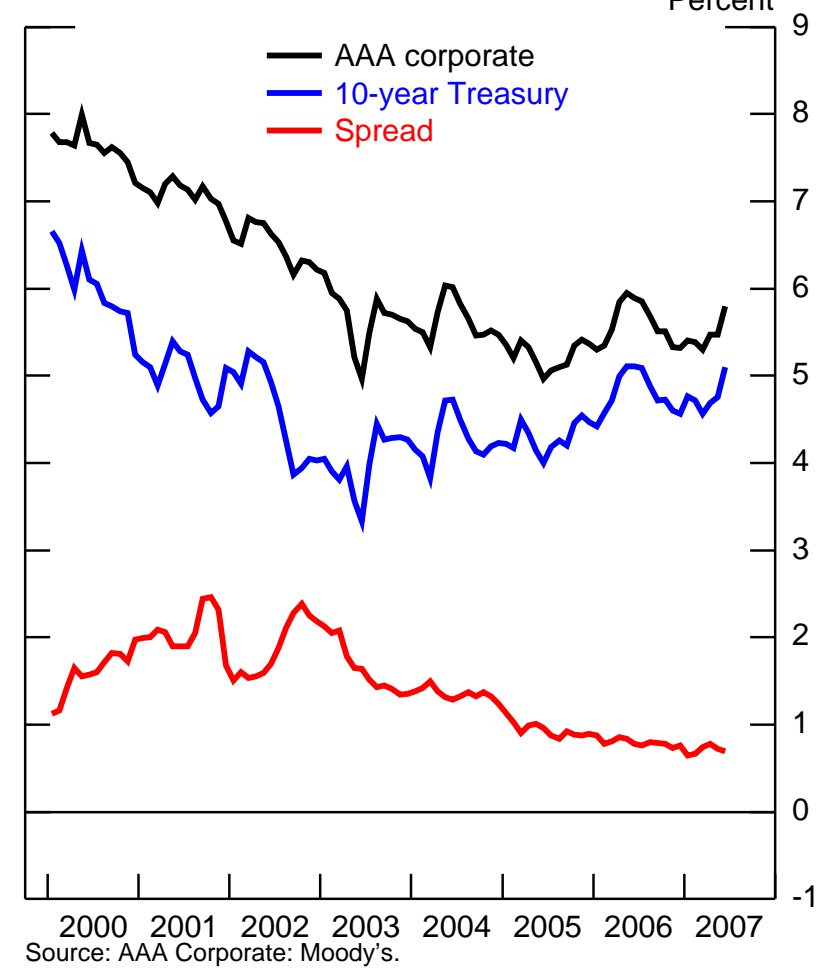

10-year U.S. Treasury and 30-year FNMA MBS yields, and spread

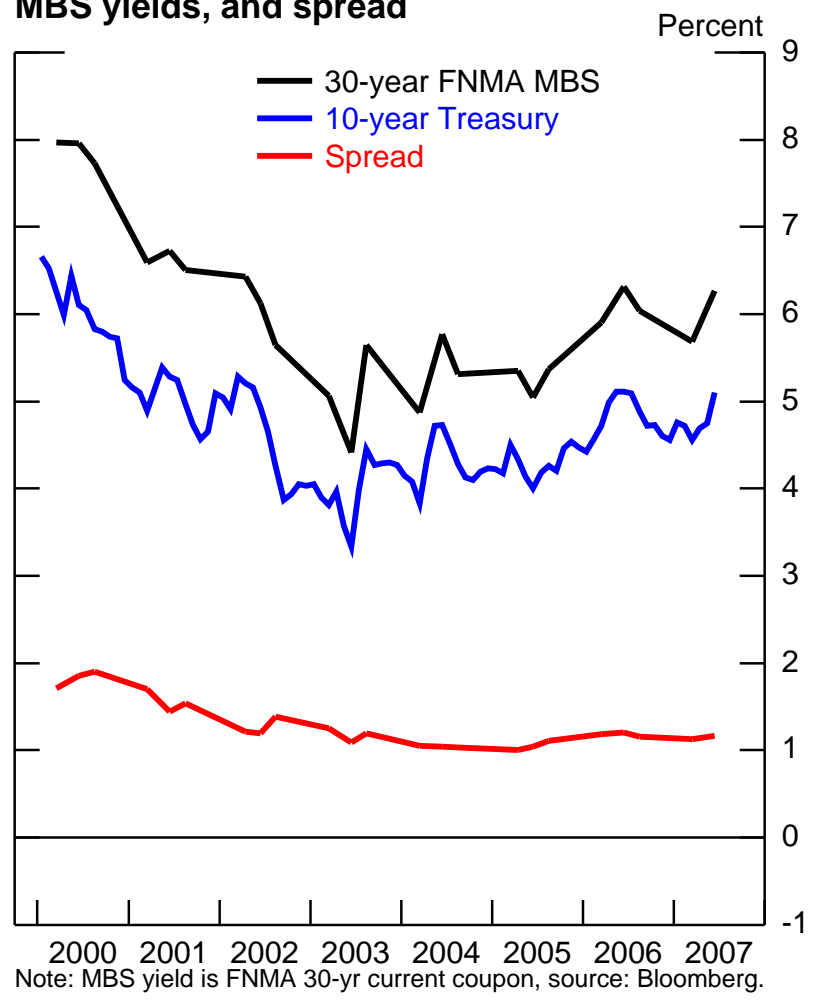

10-year U.S. Treasury and 30-year U.S. fixed mortgage rates, and spread

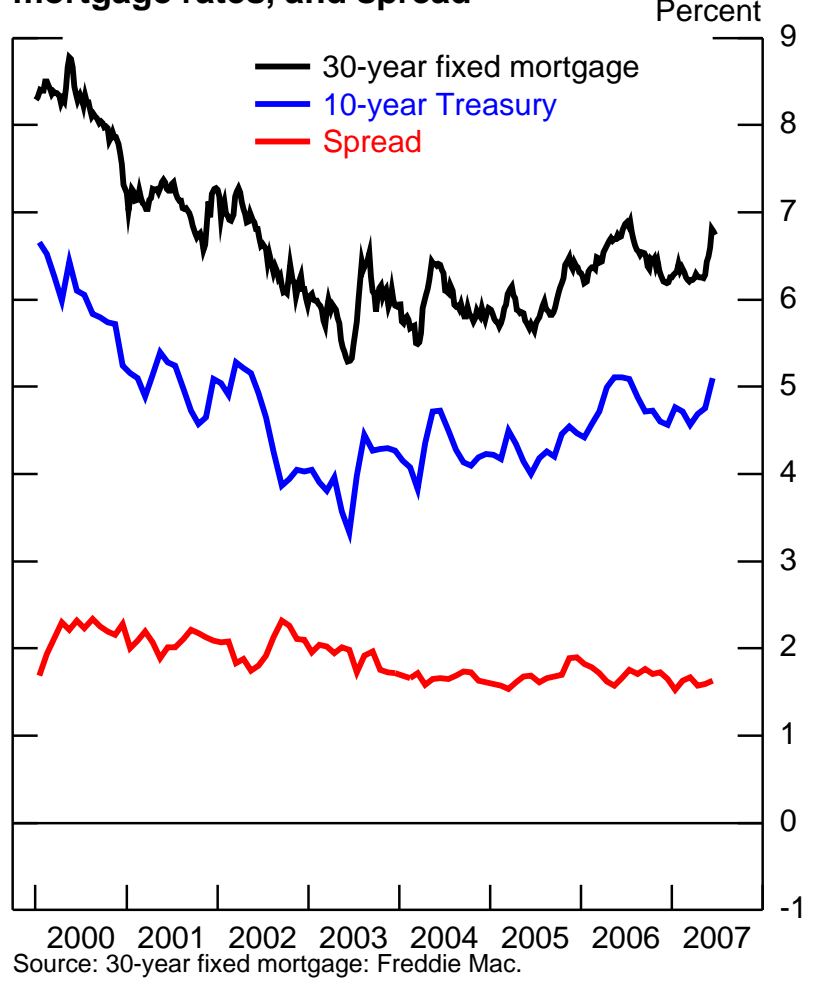


Figure 17

\section{Selected ARM rates}

Rates on Subprime and Conforming ARMS

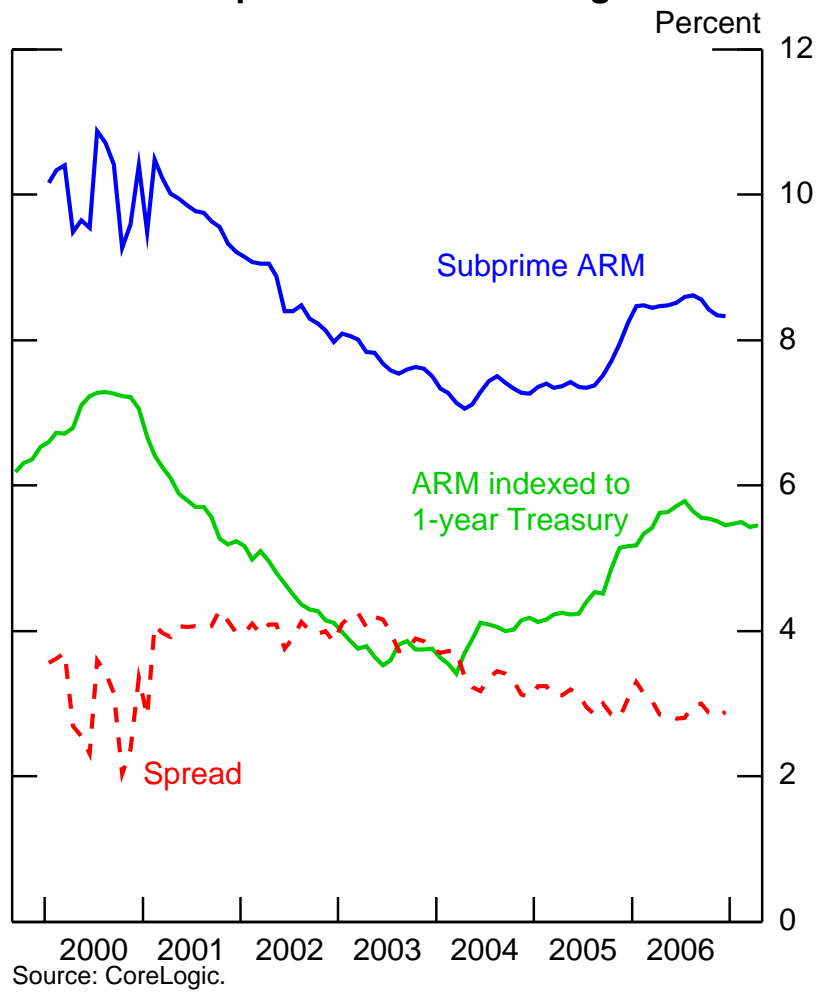

Rates on Alt-A and Conforming ARMS

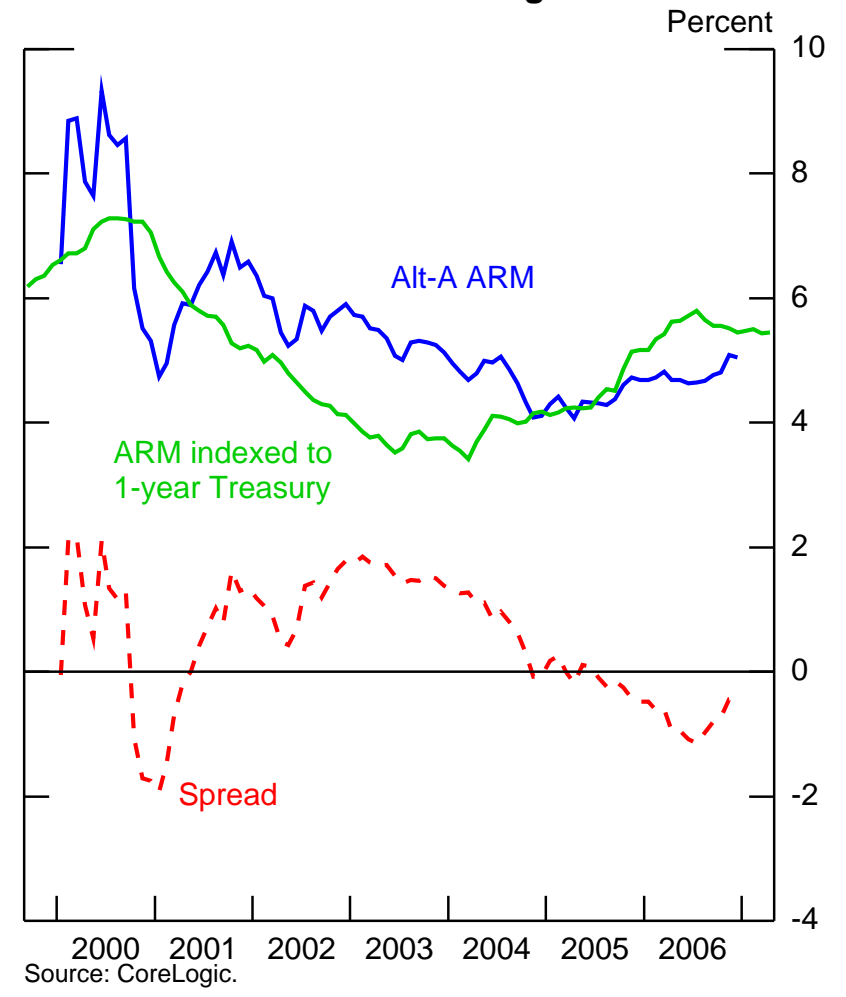

Subprime ARM Issuance

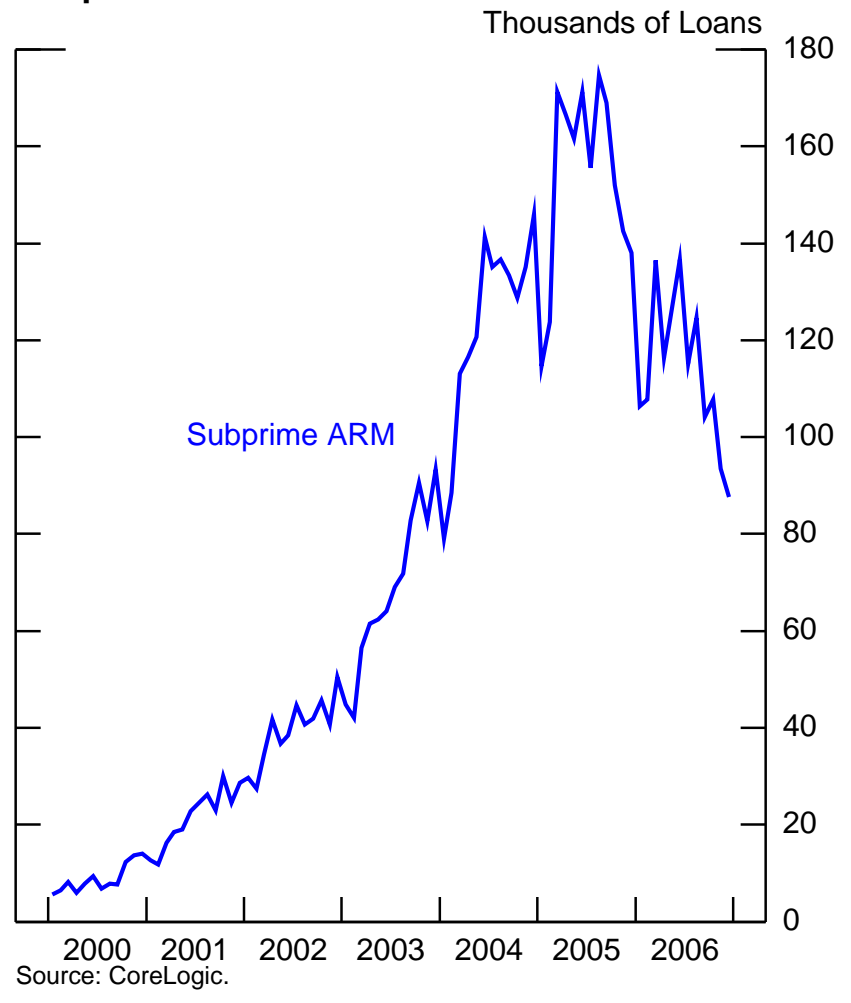

\section{Alt-A ARM Issuance}

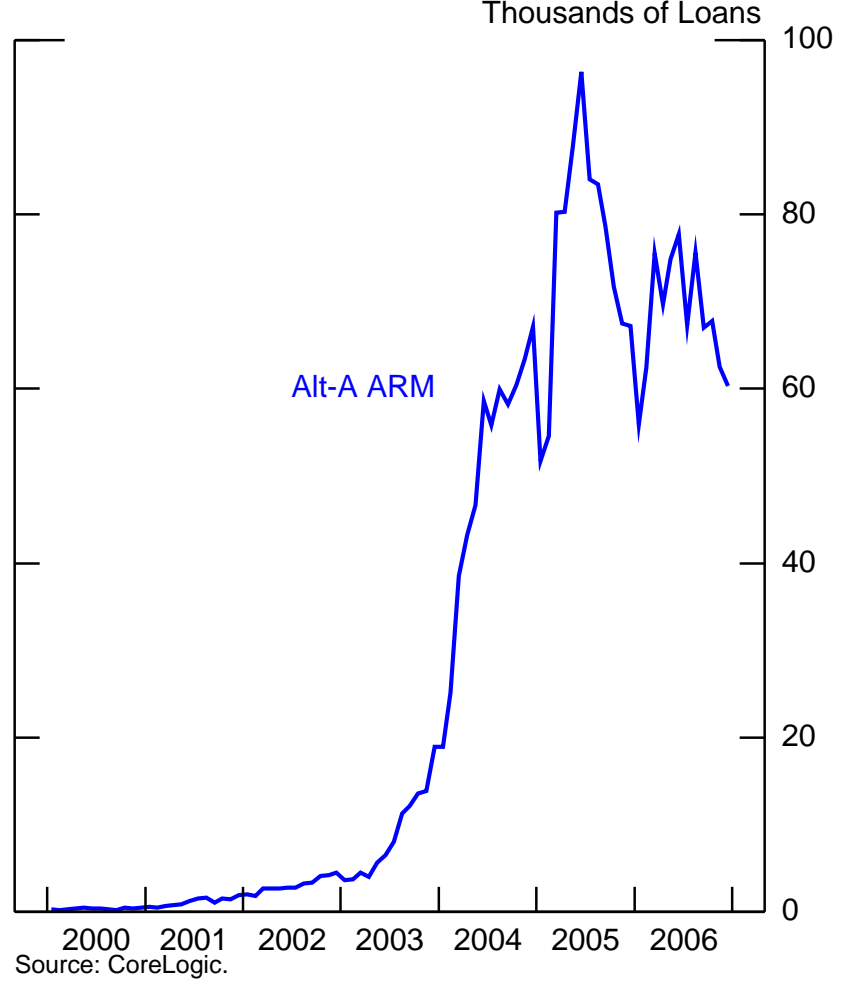


Table 1. Foreign Holdings of U.S. Securities as a Share of Outstandings

(as of June 2007, Billions of U.S. dollars)

\begin{tabular}{|c|c|c|c|c|}
\hline & & $\begin{array}{c}\text { Total } \\
\text { Outstanding }^{1}\end{array}$ & Foreign Held ${ }^{2}$ & $\begin{array}{c}\text { Foreign Share } \\
\text { of Total } \\
\text { (Percent) }\end{array}$ \\
\hline 1. & Treasury and agency securities ${ }^{3}$ & 11,688 & 3,607 & $31 \%$ \\
\hline 2. & $\begin{array}{l}\text { Corporate \& municipal credit securities (non } \\
\text { asset-backed) }{ }^{4}\end{array}$ & 8,616 & 2,045 & $24 \%$ \\
\hline 3. & Corporate $\mathrm{ABS}+\mathrm{ABCP}^{5}$ & 4,185 & 990 & $24 \%$ \\
\hline 4. & Corporate equities and fund shares & 27,768 & 3,130 & $11 \%$ \\
\hline
\end{tabular}

Notes

1. Source: Flow of Funds March 6, 2008 Z.1 Statistical Release, tables L.200-L.228 (Federal Reserve Board, 2008). See note 5 for $\mathrm{ABS}$ and $\mathrm{ABCP}$ outstandings.

2. Foreign holdings were obtained from tables 1, 23 and 24 of the "Report on Foreign Portfolio Holdings of U.S. Securities," as of June 30, 2007 (Department of the Treasury, 2008) with slight modifications to foreign held corporate ABCP from Beltran, Pounder, Thomas (2008).

3. Total includes savings bonds and holdings of the Federal Reserve System.

4. Includes open market paper.

5. Source for ABS is Flow of Funds March 6, 2008, Tables L.218 through L.222. The source for ABCP is Beltran, Pounder, Thomas (2008), using Moodys data. 
Table 2: Effects of Foreign Securities Purchases on U.S. Interest Rates

\begin{tabular}{|c|c|c|c|c|c|}
\hline Dependent Variable: & $\begin{array}{c}10-y r . \\
\text { Treasury } \\
\text { Yield }\end{array}$ & $\begin{array}{c}\text { 30-yr. Fixed } \\
\text { Mortgage } \\
\text { Rate }\end{array}$ & $\begin{array}{c}\text { Fannie Mae } \\
\text { MBS Yield }\end{array}$ & $\begin{array}{c}\text { AAA } \\
\text { Corporate } \\
\text { Yield }\end{array}$ & $\begin{array}{c}\text { AAA } \\
\text { Corporate } \\
\text { Yield }\end{array}$ \\
\hline \multicolumn{6}{|l|}{ Regressors: } \\
\hline Foreign Official Holdings & -2.817 & -2.851 & -2.790 & -3.684 & \\
\hline of Treasuries \& Agencies* & $(-2.4)$ & $(-2.7)$ & $(-1.87)$ & $(-2.92)$ & \\
\hline Foreign Holdings of & & & & & -3.981 \\
\hline U.S. Corporate Bonds* & & & & & $(-2.42)$ \\
\hline \multirow[t]{2}{*}{ Federal Funds Rate } & 0.100 & 0.145 & 0.158 & 0.107 & 0.076 \\
\hline & $(2.30)$ & $(3.41)$ & (2.19) & $(2.88)$ & $(2.23)$ \\
\hline \multirow[t]{2}{*}{ Expected $10-y r$. Inflation Rate } & 0.286 & 0.199 & 0.215 & 0.203 & 0.140 \\
\hline & $(2.73)$ & $(2.27)$ & $(1.79)$ & $(2.41)$ & $(1.62)$ \\
\hline \multirow[t]{2}{*}{ Expected GDP Growth Rate } & 0.028 & 0.110 & -0.070 & 0.091 & 0.106 \\
\hline & $(0.26)$ & $(1.12)$ & $(-0.51)$ & $(0.91)$ & $(1.02)$ \\
\hline \multirow[t]{2}{*}{ Risk Premium } & 1.749 & 1.401 & 2.154 & 0.119 & -0.141 \\
\hline & (1.43) & $(1.27)$ & $(1.40)$ & $(0.1)$ & $(-0.12)$ \\
\hline \multirow[t]{2}{*}{ Lagged Dep. Var. } & 0.609 & 0.612 & 0.540 & 0.602 & 0.686 \\
\hline & (6.33) & (6.79) & (4.27) & $(6.44)$ & (8.54) \\
\hline \multirow[t]{2}{*}{ Constant } & 0.705 & 1.252 & 1.740 & 1.853 & 1.716 \\
\hline & $(1.08)$ & (1.83) & $(2.02)$ & $(2.3)$ & (2.01) \\
\hline Adj. R-squared & 0.921 & 0.927 & 0.878 & 0.920 & 0.917 \\
\hline Obs. & 68 & 69 & 65 & 69 & 69 \\
\hline
\end{tabular}

(t-statistics in parentheses)

*measured as a share of total outstanding Treasuries and agencies and U.S. corporate bonds, respectively. Note: Underlying data is quarterly; sample period 1990q1 - 2007q2. 
Table 3: Simulation Results

\begin{tabular}{|c|c|c|c|c|c|c|}
\hline & $\begin{array}{c}\text { Treasury } \\
\text { yield } \\
\end{array}$ & $\begin{array}{c}\text { ABS } \\
\text { yield }\end{array}$ & $\begin{array}{c}\text { Treasury } \\
\text { yield }\end{array}$ & $\begin{array}{c}\text { ABS } \\
\text { yield }\end{array}$ & $\begin{array}{c}\text { Treasury } \\
\text { yield } \\
\end{array}$ & $\begin{array}{c}\text { ABS } \\
\text { yield }\end{array}$ \\
\hline & \multicolumn{2}{|c|}{ Baseline Sensitivity } & \multicolumn{2}{|c|}{ Higher Sensitivity } & \multicolumn{2}{|c|}{ Lower Sensitivity } \\
\hline Baseline yields & 4.6 & 6.5 & 4.6 & 6.5 & 4.6 & 6.5 \\
\hline & \multicolumn{6}{|c|}{ changes from baseline: } \\
\hline $\begin{array}{l}\text { Shock 1: China's wealth }+\$ 2 \text { trillion; China's } \\
\text { Treasury \& Agency holdings }+\$ 1 \text { trillion } \\
\text { (equivalent to GSG acquisitions of Treasuries \& } \\
\text { Agencies 2003-2007) }\end{array}$ & -1.46 & -1.68 & -2.13 & -2.37 & -0.71 & -0.85 \\
\hline $\begin{array}{l}\text { Shock 2a: Europe's desired holdings of U.S. } \\
\text { corporate debt } \mathbf{\$} \mathbf{\$ 7 5} \text { billion } \\
\text { (equivalent to Europe's acquisitions of U.S. ABS } \\
2003-2007 \text { ) }\end{array}$ & -0.49 & -0.64 & -0.77 & -0.93 & -0.23 & -0.35 \\
\hline $\begin{array}{l}\text { Shock } 2 \text { b: Europe's desired holdings of U.S. } \\
\text { corporate debt }+\$ \mathbf{1 . 2 5} \text { trillion } \\
\text { (equivalent to Europe's acquisitons of all U.S. } \\
\text { corporate debt } 2003-2007 \text { ) }\end{array}$ & -1.29 & -1.68 & -2.03 & -2.45 & -0.60 & -0.93 \\
\hline $\begin{array}{l}\text { Shock 3a: Global supply of ABS }+\mathbf{\$} \mathbf{2 . 5} \text { trillion } \\
\text { (equivalent to increase in U.S. ABS outstanding, } \\
\text { 20003-2007; Europe acquires roughly } \$ 190 \\
\text { billion) }\end{array}$ & +0.71 & +1.03 & +1.33 & +1.69 & +0.15 & +0.42 \\
\hline $\begin{array}{l}\text { Shock 3b: Global supply of ABS of } \mathbf{+} \mathbf{\$ 2 . 5} \\
\text { trillion } \\
\text { (Europe has no demand sensitivity to yields on } \\
\text { Treasuries or ABS, and acquires none of the } \\
\text { increase) }\end{array}$ & +0.97 & +1.41 & +1.94 & +2.45 & +0.22 & +0.61 \\
\hline
\end{tabular}




\begin{tabular}{|c|c|c|c|}
\hline Dependent Variable: & $\begin{array}{l}\text { 10-yr. Treas. Yield } \\
-6 \text { mo. CD rate }\end{array}$ & $\begin{array}{l}\text { AAA Corp. Bond Yield } \\
-6 \text { mo. CD rate }\end{array}$ & $\begin{array}{l}\text { U.S. M2 Money } \\
\text { Supply }\end{array}$ \\
\hline \multicolumn{4}{|l|}{ Regressors: } \\
\hline \multirow[t]{2}{*}{ 10-yr. Treasury Yield } & & 1.210 & -0.063 \\
\hline & & $(25.88)$ & $(-4.88)$ \\
\hline \multirow[t]{2}{*}{ AAA Corp. Bond Yield } & 0.768 & & 0.051 \\
\hline & $(27.67)$ & & (4.95) \\
\hline \multirow[t]{2}{*}{ Treasuries/Wealth } & 2.807 & & \\
\hline & $(2.55)$ & & \\
\hline \multirow[t]{2}{*}{ Corp. Bonds/Wealth } & & 2.222 & \\
\hline & & (1.39) & \\
\hline \multirow[t]{2}{*}{ U.S. GDP/U.S. Wealth } & & & 0.221 \\
\hline & & & $(2.48)$ \\
\hline \multirow{2}{*}{ Expected 10-yr. Ahead Inflation Rate } & -0.031 & 0.070 & 0.050 \\
\hline & $(-0.61)$ & $(0.62)$ & $(4.92)$ \\
\hline Expected 1-yr. Ahead Inflation Rate & -0.160 & 0.024 & -0.017 \\
\hline - Expected 10-yr. Ahead Inflation Rate & $(-1.09)$ & $(0.12)$ & $(-1.59)$ \\
\hline \multirow[t]{2}{*}{ Federal Budget Deficit/U.S. GDP } & 0.126 & -0.133 & 0.006 \\
\hline & $(6.36)$ & $(-4.88)$ & $(2.33)$ \\
\hline \multirow[t]{2}{*}{ Expected GDP Growth Rate } & -0.014 & 0.039 & 0.007 \\
\hline & $(-0.27)$ & $(0.59)$ & (1.92) \\
\hline \multirow[t]{2}{*}{ Constant } & -1.253 & 0.427 & 0.009 \\
\hline & $(-4.87)$ & $(0.71)$ & $(0.23)$ \\
\hline Adj. R-squared & 0.960 & 0.946 & 0.920 \\
\hline Obs. & 83 & 83 & 85 \\
\hline
\end{tabular}

(Z-statistics in parentheses)

Note: Underlying data is quarterly; sample period $1980 q 1$ to $2007 q 2$. 